\title{
Response of white maize hybrids to plant densities and nitrogen fertilizer rates
}

\author{
Ali A. El-Hosary; Gaber Y. Hammam, El-Saeed M. M. El-Gedwy and Mohamed E. Sidi \\ Agronomy Department, Faculty of Agriculture, Benha University, Egypt \\ Corresponding author: alsaeed.algedwy@fagr.bu.edu.eg
}

\begin{abstract}
Two field experiments were conducted on the Farm of Agric. Res. and Exp. Center of Fac. of Agric. Moshtohor, Benha University, Toukh Directorate, Qalyubia Governorate, Egypt, during the two successive summer growing seasons of 2016 and 2017 to study the effect of three plant population densities i.e. 20000, 24000 and 28000 plants/feddan (fed) and three nitrogen fertilizer rates, i.e. 90,120 and $150 \mathrm{~kg} \mathrm{~N} / \mathrm{fed}$ on the growth traits, yield components, yield and some kernels chemical properties of three white single cross hybrids of maize (S.C. 7071, S.C. 30K8 and S.C. 2031). The obvious results of this investigation can be summarized as follows: Increasing plant population density from 20000 to 28000 plants/fed significantly increased mean values of No. of days from planting to $50 \%$ tasseling and silking, leaf area index, plant height $(\mathrm{cm})$, ear height $(\mathrm{cm})$ No. of barren plants/fed, No. of ears/fed, stover yield/fed $(\mathrm{kg})$ and biological yield/fed $(\mathrm{kg})$ in both seasons. On the other hand, mean values of No. of green leaves/plant, leaf area/plant $\left(\mathrm{cm}^{2}\right)$, No. of plants carried two ears/fed, No. of kernels/ear, ear weight (g), shelling (\%), 100-kernel weight $(\mathrm{g})$, ear yield/fed $(\mathrm{kg})$, grain yield/fed $(\mathrm{kg})$, harvest index, nitrogen uptake/fed $(\mathrm{kg})$ and protein yield/fed $(\mathrm{kg})$ were significantly decreased in the two seasons. Allmost traits of maize under study were significantly increased by increasing nitrogen fertilizer rates from 90 and 120 to $150 \mathrm{~kg} \mathrm{~N} / \mathrm{fed} \mathrm{except,} \mathrm{No.} \mathrm{of} \mathrm{days} \mathrm{to} 50 \%$ tasseling and silking as well as No. of barren plants/fed were significantly decreased with increasing nitrogen rates in the both seasons, nitrogen fertilizer rate of 150 gave the best mean values for all maize traits under study. White single cross hybrids of maize were significantly differed in all maize traits under study in the both seasons. Maize hybrid of S.C. 30K8 was significantly surpassed S.C. 7071 and S.C. 2031 in mean values of No. of plants carried two ears/fed, No. of ears/fed, No. of kernels/ear, grain yield/fed and harvest index as well as gave the lowest mean values of No. of barren plants/fed and the shortest period from planting to $50 \%$ tasseling or silking in the both seasons. Moreover, S.C. 2031 surpassed the other two maize hybrids in mean values of leaf area/plant, leaf area index, ear weight, 100-kernel weight, ear yield/fed, biological yield/fed, nitrogen uptake/fed and protein yield/fed in the two seasons. Meanwhile, S.C. 7071 recorded the highest mean values of No. of green leaves/plant, plant height, ear height, shelling $\%$ and stover yield/fed in the two seasons. The first order interactions between $(20000$ plants/fed X $150 \mathrm{~kg} \mathrm{~N} / \mathrm{fed}),(24000$ plants/fed X S.C. $30 \mathrm{~K} 8)$, (20000 plants/fed X S.C. 2031) and (150 kg N/fed X S.C. $30 \mathrm{~K} 8)$ as well as the second order interactions between (24000 plants/fed X $150 \mathrm{~kg} \mathrm{~N} / \mathrm{fed}$ X S.C. $30 \mathrm{~K} 8$ ) and (20000 plants/fed X $150 \mathrm{~kg} \mathrm{~N} /$ fed X S.C. 2031) were significantly recorded the greatest grain yield/fed as compared with the others interactions in the both seasons.

It could be summarized that, when planting maize hybrid of $30 \mathrm{~K} 8$ the best plant population density was 24000 plants/fed, meanwhile, when planting maize hybrids of S.C. 2031 or S.C. 7071 the best plant population density of 20000 plants/fed with soil fertilized by $150 \mathrm{~kg} \mathrm{~N} / \mathrm{fed}$ to maximized grain yield/fed.
\end{abstract}

Keywords: maize hybrids, S.C. 2031, S.C. 30K8, S.C. 7071, plant densities, Nitrogen fertilizer

\section{Introduction}

Maize (Zea mays, L.) is globally the top ranking cereal in potential grain productivity. It is considered as a 'King of cereals crops' because of its special characteristics that include its carbon pathway (C4), wider adaptability, higher multiplication ratio, desirable architecture, superior transpiration efficiency and high versatile use. In Egypt, maize is considered as one of the main cereal crops, comes the third after wheat and rice. Maize is very essential either for the human food or animal feeding and a common ingredient for industrial products. It plays a vital source of daily human food because their flour mixed with wheat flour by $20 \%$ for bread making. Also, maize is used as a feed for livestock whether fresh, silage or grains. Therefore, a great attention should be paid to raise maize productivity by maximizing yield per unit area in order to reduce the gap between its production and consumption. Where, maize is well known for its high demand for nutrients and other production inputs. Thereby, among factors that enhances maize productivity through growing high yielding hybrids under the optimum plant population density and applying the optimum nitrogen fertilizer rate. World average cultivated area of maize in 2017 year (www.fao.org) reached 469.49 million fed one fed $=4200 \mathrm{~m}^{2}$; the total production was 1134.75 million tonnes, with an average productivity of $2416.97 \mathrm{~kg}$ grain/fed. The growing area of maize in Egypt during 2017 year is about 2.192 million fed with a total grain yield of 7.10 million tonnes. The average grain yield production/fed was about $3239.19 \mathrm{~kg}$. The total 
production supplies 40-50 \% of the require consumption with a reduction gap of 50-60\% which has to be filled via importation.

Increasing plant population density of maize significantly increased No. of days from planting to $50 \%$ tasseling and silking, leaf area index, plant height $(\mathrm{cm})$, ear height $(\mathrm{cm})$, No. of plants/fed, No. of barren plants/fed, No. of ears/fed, stover yield/fed $(\mathrm{kg})$, ear yield/fed $(\mathrm{kg})$, grain yield/fed $(\mathrm{kg})$ and biological yield/fed $(\mathrm{kg})$. On the other hand, No. of green leaves/plant, area of topmost ear leaf $\left(\mathrm{cm}^{2}\right)$, leaf area/plant $\left(\mathrm{cm}^{2}\right)$, No. of plants carried two ears/fed, No. of ears/plant, No. of rows/ear, No. of kernels/row, No. of kernels/ear, ear weight (g), kernels shelling $(\%)$, 100-kernel weight $(\mathrm{g})$, grain yield/plant $(\mathrm{g})$, harvest index $(\%)$, kernels nitrogen content, kernels crude protein content, nitrogen uptake/fed $(\mathrm{kg})$ and protein yield/fed $(\mathrm{kg})$ were significantly decreased (El-Habbak 1996; El-Sheikh 1998; El-Agamy et al. 1999; El-Koomy 2000; Agasibagil 2006; Saeed et al. 2007; Hassan et al. 2008; Sallah et al. 2009; Sharifi et al. 2009; Gozubenli 2010; Gomaa et al. 2011; Lashkari et al. 2011; Sharifi and Pirzad 2011; Zamir et al. 2011; Dawadi and Sah 2012; El-Gedwy et al. 2012; Robles et al. 2012; Shafi et al. 2012; Adeniyan 2014; Ahmadu 2014; Timlin et al. 2014; Imran et al. 2015; Karki et al. 2015 Mahdi and Ismail 2015; Gobeze et al. 2016; Mandić et al. 2016; Rahman et al. 2016; Sharanabasappa et al. 2017; Eyasu et al. 2018 and Zeleke et al. 2018).

Nitrogen is the component of protoplasm, proteins, nucleic acids, chlorophyll and plays a vital role in both vegetative and reproductive phase of crop growth. Maize has been recognized as a heavy feeder and uses more of nitrogen than any other nutrient element. Many reports indicated that nitrogen fertilizer has more influence on the growth and yield of maize than any other plant nutrient because it is the nutrient most often deficient in the Egyptian soils. Thus, increasing application of nitrogen fertilizer rates led to significant increases in growth, yield and its attributes and quality characters of maize crop (El-Habbak 1996; El-Sheikh 1998; El-Agamy et al. 1999; Saeed et al. 2007; Sallah et al. 2009; Szulc 2009; Bamuaafa et al. 2010; ElGedwy et al. 2011; EL-Hosary et al. 2011; Hokmalipour and Darbandi 2011; Dawadi and Sah 2012; Karasu 2012; Li et al. 2012; Kandil 2013; Radma and Dagash 2013; Adeniyan 2014; Ahmadu 2014; Delibaltova 2014; Khan et al. 2014; Rehman et al. 2014; Hafez and Abdelaal 2015; Kandil et al. 2016; Gharibi et al. 2016; Majid et al. 2017; Marković et al. 2017; Sapkota et al. 2017; Sharanabasappa et al. 2017; Takele et al. 2017; Ahmad et al. 2018 and Zeleke et al. 2018).

Several investigators showed that maize hybrids differed in growth, yield components, yield and some chemical properties (El-Habbak 1996; El-Sheikh 1998; El-Agamy et al. 1999; El-Koomy 2000;
Agasibagil 2006; Saeed et al. 2007; Hassan et al. 2008; Sallah et al. 2009; Szulc 2009; Bamuaafa et al. 2010; Hokmalipour and Darbandi 2011; Dawadi and Sah 2012; Karasu 2012; Li et al. 2012; Kandil 2013; Radma and Dagash 2013; Adeniyan 2014; Ahmadu 2014; Delibaltova 2014; Khan et al. 2014; Rehman et al. 2014; Hafez and Abdelaal 2015; Karki et al. 2015; El-Mehy et al. 2016; Kinfe et al. 2016; Majid et al. 2017; Marković et al. 2017; Ahmad et al. 2018 and Eyasu et al. 2018).

The aim of this investigation was designed to study the effect of plant population densities and nitrogen fertilizer rates on growth, yield components, yield and kernels chemical properties in three white single cross hybrids of maize.

\section{Materials and Methods}

Two field experiments were carried out at the Farm of Agricultural Research and the Experimental Center of Faculty of Agriculture at Moshtohor, (Toukh Directorate, Qalyubia Governorate) Benha Univ. Egypt, during the two summer successive growing seasons of 2016 and 2017. This study was to investigate the performance of three white single cross hybrids of maize, i.e. single cross 7071 for Tech Seed Company (S.C. 7071), single cross $30 \mathrm{~K}$ 08 for Pioneer hybrids (S.C. 30K8) and single cross hybrid 2031 for Misr Hytech Seed Int. (S.C. 2031) to three nitrogen fertilizers rates, i.e. 90,120 and $150 \mathrm{~kg}$ $\mathrm{N} /$ fed and three plant population densities treatments (20000 plants/fed from grown in ridges $70 \mathrm{~cm}$ apart and $30 \mathrm{~cm}$ between hills), (24000 plants/fed from grown in ridges $70 \mathrm{~cm}$ apart and $25 \mathrm{~cm}$ between hills) and (28000 plants/fed from grown in ridges $70 \mathrm{~cm}$ apart and $21.43 \mathrm{~cm}$ between hills) on the growth traits, yield components, yield and kernels chemical properties.

Soil texture of the experimental site was clay of $\mathrm{pH}$ nearly of 8.0. The chemical and mechanical properties analysis of the experimental soil were determined according to the standard procedures described by Black and Evans (1965) and represented in Table 1 in each of the two growing seasons.

The preceding winter crop in the two seasons was wheat (Triticum aestivum, L.). The experimental design was laid out using randomized complete block design (RCBD) using split split plot design in three replications. Each of the three plant densities were distributed in the main plots, whereas the three nitrogen fertilizer rates were arranged at random in sub plots and the three white single cross hybrids of maize were assigned at random in sub sub plots. The sub sub plot area was $10.5 \mathrm{~m}^{2}$ and contained five ridges of $3 \mathrm{~m}$ long and $70 \mathrm{~cm}$ apart. Phosphorous fertilizer was applied in form of Calcium super phosphate $\left(\begin{array}{llll}12.5 & \% & \mathrm{P}_{2} \mathrm{O}_{5}\end{array}\right)$ at a rate of $100 \mathrm{~kg} / \mathrm{fed}$ during soil preparation in each season. Experiments 
were planted on May $23^{\text {th }}$ and $29^{\text {th }}$ of in the first season (2016) and the second season (2017), respectively. Maize plants were thinned before the first irrigation to one plant/hill. Nitrogen fertilizer was applied in form of urea $(46 \% \mathrm{~N})$, and divided into two equal parts and applied before the first and second irrigation in each season. The first irrigation was applied after 21 days from sowing and the following irrigations were applied at 12-15 days intervals during the growing seasons. Maize plants were harvested on $17^{\text {th }}$ and $23^{\text {th }}$ of September in the first and the second seasons, respectively. The other agricultural practices were kept the same as normally practiced in maize fields according to the recommendations of Ministry of Agriculture and Land Reclamation, except for the factors under study.

Table 1: Chemical and mechanical properties of the experimental soil units at planting maize during 2016 and 2017 seasons.

\begin{tabular}{lcc}
\hline \multirow{2}{*}{ Properties } & \multicolumn{2}{c}{ Season } \\
\cline { 2 - 3 } Chemical analysis & $\mathbf{2 0 1 6}$ & $\mathbf{2 0 1 7}$ \\
\hline E.C. & 2.28 & 2.31 \\
pH $(1: 2.5)$ & 8.12 & 8.09 \\
CaCo $\%$ & 3.21 & 2.94 \\
O.M \% & 2.28 & 2.31 \\
N \% (total) & 0.19 & 0.20 \\
N (ppm) (available) & 61.93 & 63.72 \\
P \% (total) & 0.120 & 0.125 \\
P (ppm) (available) & 23.80 & 25.12 \\
K \% (total) & 0.62 & 0.63 \\
K (ppm) (available) & 919.06 & 969.98 \\
\hline Particle size distribution (mechanical analysis ) \\
\hline Course sand \% & 6.93 & 5.50 \\
Find sand \% & 27.28 & 28.64 \\
Silt \% & 13.23 & 11.60 \\
Clay \% & 52.58 & 54.26 \\
Texture grade & Clay & Clay \\
\hline
\end{tabular}

\section{Studied characteristics:}

\section{A- Growth characteristics:}

1- Time of tasseling was determined as the No. of days from planting to $50 \%$ tasseling.

2- Time of silking was determined as the No. of days from planting to $50 \%$ silking.

3- Number of green leaves/plant at 80 days after planting.

4- Leaf area/plant $\left(\mathrm{cm}^{2}\right)$ at 80 days after planting. It was calculated from the following equation: Leaf area/plant $=$ Area of topmost ear leaf $X$ No. of green leaves/plant

Where, Area of topmost ear leaf $\left(\mathrm{cm}^{2}\right)$ at 80 days after planting was estimated as described by Stickler, 1964. It was calculated from the following equation:
Area of topmost ear leaf $=$ Ear leaf length $X$ Greatest leaf width X 0.75

5- Leaf area index at 80 days after planting was estimated as described by Stickler, 1964. It was estimate from the following formula:

$$
\text { Leaf area index }=\frac{\text { Leaf area } / \text { plant }}{\text { land area } / \text { plant }}
$$

6- Plant height $(\mathrm{cm})$ at harvest, from the soil surface to the top of tassel.

7- Ear height $(\mathrm{cm})$ at harvest, from the soil surface to the base of the topmost ear.

8- Number of plants carried two ears/fed at harvest.

9- Number of barren plants/fed at harvest.

10 -Number of ears/fed at harvest.

Ten plants were chosen from the three center ridges at random from each sub plots to determine No. of green leaves/plant, area of topmost ear leaf $\left(\mathrm{cm}^{2}\right)$, leaf area/plant $\left(\mathrm{cm}^{2}\right)$, leaf area index, plant height $(\mathrm{cm})$ and ear height $(\mathrm{cm})$. Whereas, the tasseling and silking dates, No. of plants carried two ears/fed, No. of barren plants/fed and No. of ears/fed were estimated from the whole plants in the three center ridges.

\section{B- Yield and yield components:}

1- Number of kernels/ear.

2- Ear weight (g).

3- Shelling $\%$. It was calculated by using the following formula:

$$
\text { Shelling }(\%)=\frac{\text { Weight of kernels/ear }(\mathrm{g})}{\text { Ear weight }(\mathrm{g})} X \mathbf{1 0 0}
$$

4- Weight of 100-kernel (g).

5- Stover yield/fed $(\mathrm{kg})$.

6- Ear yield/fed (kg).

7- Grain yield/fed (kg), adjusted to $15.5 \%$ moisture content. It was calculated by using the following formula:

Grain yield $/$ fed $(\mathbf{k g})=\frac{\text { Ear yield } / \text { fed }(\mathbf{k g}) \times \text { Shelling } \%}{\mathbf{1 0 0}}$

8- Biological yield/fed (kg). It was calculated by using the following formula:

Biological yield $/ \mathbf{f e d}(\mathbf{k g})=$ Ear yield $/ \mathbf{f e d}(\mathbf{k g})+$ Stover yield $/ \mathbf{f e d}(\mathbf{k g})$

9- Harvest index (\%). It was calculated by using the following formula:

$$
\text { Harvest index }(\%)=\frac{\text { Grain yield } / \text { fed }(\mathrm{kg})}{\text { Biological yield } / \text { fed }(\mathrm{kg})} \times 100
$$

Ten ears were chosen from the three center ridges at random from each sub plots to determine No. of kernels/ear, ear weight $(\mathrm{g})$, kernels weight/ear $(\mathrm{g})$, shelling $\%$ and 100-kernel weight. Whereas, ear yield/fed $(\mathrm{kg})$, stover yield/fed $(\mathrm{kg})$, grain yield/fed $(\mathrm{kg})$, biological yield/fed $(\mathrm{kg})$ and harvest index $(\%)$ were estimated from the whole plants in the three center ridges.

\section{C- Chemical analysis}

Maize kernels samples were taken after harvest at random from all kernels of ten ears to determine:

1- Nitrogen uptake/fed $(\mathrm{kg})=$ grain yield $(\mathrm{kg}) \mathrm{x}$ kernels nitrogen content (\%)

Where, Kernels nitrogen content (\%) was determinate according to the modified micro Kjeldahl method (A. O. A. C., 1990). 
2- Protein yield/fed $(\mathrm{kg})$ = grain yield $(\mathrm{kg}) \mathrm{x}$ kernels crude protein content $(\%)$

Where, Kernels crude protein content $(\%)$ was calculated by multiplying nitrogen content $(\%)$ X 6.25 (A. O. A. C., 1990).

\section{Statistical analysis:}

The analysis of variance was carried out according to the procedure described by Gomez and Gomez (1984). Data were statistically analyzed according to using the MSTAT-C Statistical Software Package (Michigan State University, 1983). Where the F-test showed significant differences among means L. S. D. test at 0.05 level was used to compare between means

\section{Results and Discussion}

\section{Effect of plant population densities:}

Results presented in Tables 2, 3 and 4 revealed that the differences between the studied three plant population densities, i.e. 20000, 24000 and 28000 maize plants/fed were significant on flowering, growth, yield components, yield and kernels properties during the two seasons. Data revealed that planting 20000 maize plants/fed gave the greatest mean values of No. of green leaves/plant (13.69 and 13.33 leaves), leaf area/plant (9338.38 and 8899.59 $\mathrm{cm}^{2}$ ), No. of plants carried two ears/fed (2222.22 and 1600.00 plants), No. of kernels/ear (584.70 and 592.30 kernels), ear weight (215.69 and $217.08 \mathrm{~g}$ ), shelling percentage (82.01 and $81.64 \%)$, 100-kernel weight (34.53 and $33.58 \mathrm{~g})$, ear yield/fed (3935.19 and $3992.59 \mathrm{~kg})$, grain yield/fed (3214.17 and $3254.50 \mathrm{~kg}$ ), harvest index (43.14 and $43.41 \%$ ), nitrogen uptake/fed (56.04 and $56.32 \mathrm{~kg}$ ) and protein yield/fed $(350.22$ and $352.00 \mathrm{~kg})$ in the first and second seasons, respectively. In the 2016 season, planting maize at plant density of 20000 plants/fed increased grain yield/fed by 3.33 and $21.09 \%$ compared with the growing maize at plant densities of 24000 and 28000 plants/fed respectively, the respective corresponding in the second season, were 3.44 and $30.46 \%$. It could be noticed that planting 20000 maize plants/fed was superior to the other plant densities treatments in increasing grain yield/fed. Such increase in grain yield/fed at planting density of 20000 plants/fed could be due to the increases No. of plants carried two ears/fed, No. of kernels/ear, ear weight, shelling \% and 100-kernel weight. This trend could be explained on the fact that in case of low population density produced by increasing hill spacing resulted in low competition between it for nutrient elements, soil moisture and sun light, plants would have better opportunity to produce more metabolite contents and positive effect on plant growth and productivity as well as increased translocation and consequently accumulation of metabolites through kernels and gave the maximum values of plant traits and yield components. The greatest values of No. of days from planting to $50 \%$ tasseling (66.33 and 65.93 days), No. of days from planting to $50 \%$ silking (69.04 and 68.81 days), leaf area index (5.355 and 5.322), plant height (315.93 and $322.59 \mathrm{~cm})$, ear height $(160.00$ and $162.59 \mathrm{~cm})$, No. of barren plants/fed (681.48 and 977.78 plants), No. of ears/fed (26785.19 and 26488.89 ears), stover yield/fed (4796.30 and $4611.11 \mathrm{~kg})$ and biological yield/fed (8144.44 and $7801.85 \mathrm{~kg}$ ) in the first and second seasons, respectively were obtained from planting 28000 maize plants/fed. Increasing population density from 20 to 24 and 28 thousand plants/fed significantly increased stover yield/fed by 18.27 and $36.39 \%$ respectively, in the first season. The corresponding increases were 10.65 and $31.33 \%$ in the second season for the respective densities. Such increase in stover yield/fed could be due to the increase in plant height, leaf area index and No. of plants/fed. The increases in plant height by increasing plant densities is mainly due to the increased intraspecific competition among maize plants for light and decrease in light penetration, interception and photosynthetic efficiency at higher densities as well as higher dense of plants excessive shade exist which help to produce more content of gibberellin in tissues and consequently higher plants formed. These results are in harmony with those reported by El-Habbak 1996; El-Sheikh 1998; El-Agamy et al. 1999; ElKoomy 2000; Agasibagil 2006; Saeed et al. 2007; Hassan et al. 2008; Sallah et al. 2009; Sharifi et al. 2009; Gozubenli 2010; Gomaa et al. 2011; Lashkari et al. 2011; Sharifi and Pirzad 2011; Zamir et al. 2011; Dawadi and Sah 2012; ElGedwy et al. 2012; Robles et al. 2012; Shafi et al. 2012; Adeniyan 2014; Ahmadu 2014; Timlin et al. 2014; Imran et al. 2015; Karki et al. 2015 Mahdi and Ismail 2015; Gobeze et al. 2016; Mandić et al. 2016; Rahman et al. 2016; Sharanabasappa et al. 2017; Eyasu et al. 2018 and Zeleke et al. 2018.

\section{Effect of nitrogen fertilizer rates:}

Results in Tables 2, 3 and 4 indicated that increasing nitrogen fertilizer rates from 90 up to 150 $\mathrm{kg} \mathrm{N} /$ fed caused significant increments in mean values of allmost maize characteristics except, mean values of No. of days from planting to $50 \%$ tasseling and silking as well as No. of barren plants/fed which significantly decreased with increasing nitrogen rates in 2016 and 2017 seasons. Maize plants which fertilized by the highest nitrogen fertilizer rate $(150$ $\mathrm{kg} \mathrm{N} / \mathrm{fed}$ ) gave significantly the greatest mean values of No. of green leaves/plant (13.47 and 13.17 leaves), leaf area/plant $\left(8904.18\right.$ and $\left.8646.69 \mathrm{~cm}^{2}\right)$, leaf area index (5.044 and 4.911), plant height (305.19 and $306.30 \mathrm{~cm})$, ear height $(150.00$ and $150.56 \mathrm{~cm})$, No. of plants carried two ears/fed (1540.74 and 1259.26 plants), No. of ears/fed (24637.04 and 23851.85 ears), No. of kernels/ear (535.99 and 546.25 kernels), 
ear weight (193.24 and $192.25 \mathrm{~g})$, shelling percentage (81.23 and $80.59 \%), 100$-kernel weight (33.56 and $32.14 \mathrm{~g})$, stover yield/fed (4338.89 and $4129.63 \mathrm{~kg}$ ), ear yield/fed (4037.04 and $3920.37 \mathrm{~kg})$, grain yield/fed (3270.76 and $3158.06 \mathrm{~kg})$, biological yield/fed (8375.93 and $8050.00 \mathrm{~kg}$ ), harvest index (39.19 and $39.32 \%)$, nitrogen uptake/fed (55.90 and $54.20 \mathrm{~kg}$ ) and protein yield/fed (349.38 and 338.73 $\mathrm{kg})$ as well as recorded significantly the shortest period from planting to $50 \%$ tasseling (64.22 and 63.78 days) and silking (66.48 and 66.15 days) as well as gave the lowest mean values of No. of barren plants/fed (177.78 and 311.11 plants) in the first and second seasons, respectively. The superiority rations in the first season between the highest nitrogen rate $(150 \mathrm{~kg} \mathrm{~N} / \mathrm{fed})$ and each of 120 and $90 \mathrm{~kg} \mathrm{~N} / \mathrm{fed}$ were 2.37 and $6.38 \%$ for leaf area/plant; 2.35 and $6.30 \%$ for leaf area index; 1.67 and $4.77 \%$ for plant height; 6.58 and $16.43 \%$ for ear weight; 3.55 and $7.39 \%$ for 100-kernel weight; 3.40 and $10.21 \%$ for stover yield/fed; 7.87 and $20.38 \%$ for ear yield/fed; 8.34 and $21.62 \%$ for grain yield/fed; 5.51 and $14.88 \%$ for biological yield/fed in addition to 9.81 and $25.62 \%$ for protein yield/fed, respectively. The increases rations in the second season when maize received $150 \mathrm{~kg} \mathrm{~N} / \mathrm{fed}$ over each of 120 and $90 \mathrm{~kg} \mathrm{~N} / \mathrm{fed}$ were 1.76 and $4.25 \%$ for leaf area/plant; 1.76 and $4.22 \%$ for leaf area index; 1.72 and $4.16 \%$ for plant height; 6.09 and $16.44 \%$ for ear weight; 3.08 and $7.85 \%$ for 100-kernel weight; 2.67 and $7.11 \%$ for stover yield/fed; 4.39 and $14.99 \%$ for ear yield/fed; 4.73 and $16.01 \%$ for grain yield/fed; 3.50 and $10.81 \%$ for biological yield/fed in addition to 5.87 and $19.36 \%$ for protein yield/fed, respectively. The increase in growth traits associated with increasing nitrogen fertilization rates may be attributed to the role of nitrogen in enhancement meristematic activity and cell division, which caused increase in internodes length, No. of internodes and both of them. The increase in maize yield and its attributes because of increasing nitrogen fertilizer rates up to $150 \mathrm{~kg} \mathrm{~N} / \mathrm{fed}$ can be easily ascribed to the role of nitrogen in activating growth of plants, consequently enhancement yield components (ear dimension, No. of kernels/ear, ear weight as well as 100-kernel weight) and consequently increasing grain yield/unit area. In the other hand, nitrogen application up to 150 $\mathrm{kg} \mathrm{N} /$ fed decreased the period from sowing to $50 \%$ tasseling and silking in both seasons. This decrease may be due to enhanced growth rate and accumulate and dry matter accumulation of more assimilates and dry matter accumulation in an early stage. In addition, the increases in kernels nitrogen content \% or kernels crude protein content $\%$ by raising nitrogen rates may be due to the fact that nitrogen for essential for building up to the protoplasm amino acids and proteins. These results are in compatible with those found by El-Habbak 1996; El-Sheikh 1998; El-Agamy et al. 1999; Saeed et al. 2007; Sallah et al. 2009; Szulc 2009; Bamuaafa et al.
2010; El-Gedwy et al. 2011; Hokmalipour and Darbandi 2011; Dawadi and Sah 2012; Karasu 2012; Li et al. 2012; Kandil 2013; Radma and Dagash 2013; Adeniyan 2014; Ahmadu 2014; Delibaltova 2014; Khan et al. 2014; Rehman et al. 2014; Hafez and Abdelaal 2015; Kandil et al. 2016; Gharibi et al. 2016; Majid et al. 2017; Marković et al. 2017; Sapkota et al. 2017; Sharanabasappa et al. 2017; Takele et al. 2017; Ahmad et al. 2018 and Zeleke et al. 2018.

\section{Effect of white single cross hybrids of maize:}

Results presented in Tables 2, 3 and 4 showed that mean values of all growth traits, yield components, yield and kernels chemical properties were significant differences with the studied three white single cross hybrids of maize, i.e. S.C. 7071 , S.C. 30K8 and S.C. 2031 during 2016 and 2017 seasons. The maximum mean values of No. of plants carried two ears/fed (2266.67 and 2029.63 plants), No. of ears/fed (25333.33 and 24503.70 ears), No. of kernels/ear (541.00 and 564.02 kernels), grain yield/fed (3289.30 and $3158.74 \mathrm{~kg}$ ) and harvest index (43.20 and $42.49 \%)$ as well as the lowest mean values of No. of barren plants/fed (207.41 and 355.56 plants) and the shortest period from planting to $50 \%$ tasseling (64.04 and 62.93 days) and silking (66.37 and 65.19 days) during the first and second seasons, respectively, were obtained from planting maize hybrid of S.C. 30K8. Planting maize hybrid of S.C. $30 \mathrm{~K} 8$ increased grain yield $\mathrm{kg} / \mathrm{fed}$ by 6.27 and 26.77 $\%$ in the first season, corresponding to 3.00 and 18.30 $\%$ in second season, over grain yield/fed of S.C. 2031 and S.C. 7071 maize hybrids, respectively. Results may reveal the superiority of S.C. 2031 maize hybrid in mean values of leaf area/plant (9568.69 and $9302.48 \mathrm{~cm}^{2}$ ), leaf area index (5.413 and 5.282), ear weight (197.42 and $195.23 \mathrm{~g}), 100$-kernel weight (35.30 and $33.77 \mathrm{~g})$, ear yield/fed (4053.70 and $3996.30 \mathrm{~kg})$, biological yield/fed $(8403.70$ and $8066.67 \mathrm{~kg}$ ), nitrogen uptake/fed (58.35 and 56.25 $\mathrm{kg}$ ) and protein yield/fed (364.66 and $351.56 \mathrm{~kg}$ ) in the first and second seasons, respectively. Planting maize hybrid of S.C. 2031 increased ears yield kg/fed by 1.44 and $31.47 \%$ in 2016 season, corresponding to 3.55 and $23.74 \%$ in 2017 season, over ears yield/fed of S.C. $30 \mathrm{~K} 8$ and S.C. 7071 maize hybrids, respectively. Planting maize hybrid of S.C. 7071 gave the highest mean values of No. of green leaves/plant (13.75 and 13.64 leaves), plant height (311.30 and $317.22 \mathrm{~cm})$, ear height (177.41 and $179.63 \mathrm{~cm})$, shelling percentage (84.01 and $82.41 \%$ ) and stover yield/fed (4492.59 and $4346.30 \mathrm{~kg}$ ) in the first and second seasons, respectively. Planting maize hybrid of S.C. 7071 increased stover yield $\mathrm{kg} / \mathrm{fed}$ by 3.28 and $23.78 \%$ in 2016 season, corresponding to 6.78 and $21.04 \%$ in 2017 season, over stover yield/fed of S.C. 2031 and S.C. 30K8 maize hybrids, respectively. These differences may be due to the 
genetic differences between the three white single cross maize hybrids. Also, the differences in 100kernel weight might be attributed to the variation in translocation rate of photosynthetic from leaves to the storing organs, i.e. the kernels. The superiority of S.C. $30 \mathrm{~K} 8$ maize hybrid in grain yield/fed over the other maize hybrids might be due to the increase in yield components, namely, No. of plants carried two ears/fed, No. of ears/fed, No. of kernels/ear and harvest index. These results are in harmony with those reported by El-Habbak 1996; El-Sheikh 1998; El-Agamy et al. 1999; El-Koomy 2000; Agasibagil 2006; Saeed et al. 2007; Hassan et al. 2008; Sallah et al. 2009; Szulc 2009; Bamuaafa et al. 2010; ELHosary et al. 2011; Hokmalipour and Darbandi 2011; Dawadi and Sah 2012; Karasu 2012; Li et al. 2012; Kandil 2013; Radma and Dagash 2013; Adeniyan 2014; Ahmadu 2014; Delibaltova 2014; Khan et al. 2014; Rehman et al. 2014; Hafez and Abdelaal 2015; Karki et al. 2015; El-Mehy et al. 2016; Kinfe et al. 2016; Majid et al. 2017; Marković et al. 2017; Ahmad et al. 2018 and Eyasu et al. 2018 showed that hybrids markedly varied for almost growth, yield, yield components and kernels chemical properties of maize.

Table 2. Mean values of No. of days to $50 \%$ tasseling, No. of days to $50 \%$ silking, No. of green leaves/plant, plant leaf area $\left(\mathrm{cm}^{2}\right)$, leaf area index, plant height $(\mathrm{cm})$ and ear height $(\mathrm{cm})$ as affected by mean effect of plant population densities, nitrogen fertilizer rates and white single hybrids of maize during 2016 and 2017 seasons.

\begin{tabular}{|c|c|c|c|c|c|c|c|c|c|c|c|c|c|}
\hline \multirow[t]{2}{*}{ Treatment } & & $\begin{array}{c}\text { No. of days } \\
\text { to } 50 \% \\
\text { tasseling }\end{array}$ & $\begin{array}{l}\text { No. of days } \\
\text { to } 50 \% \\
\text { silking }\end{array}$ & \multicolumn{2}{|c|}{$\begin{array}{c}\begin{array}{c}\text { No. of } \\
\text { green }\end{array} \\
\text { leaves/plant }\end{array}$} & \multicolumn{2}{|c|}{$\begin{array}{l}\text { Plant leaf area } \\
\left(\mathrm{cm}^{2}\right)\end{array}$} & \multicolumn{2}{|c|}{$\begin{array}{l}\text { Leaf area } \\
\text { index }\end{array}$} & \multicolumn{2}{|c|}{$\begin{array}{c}\text { Plant height } \\
(\mathrm{cm})\end{array}$} & \multicolumn{2}{|c|}{$\begin{array}{c}\text { Ear height } \\
(\%)\end{array}$} \\
\hline & & $2016 \quad 2017$ & $2016 \quad 2017$ & 2016 & 2017 & & & & & & & & \\
\hline
\end{tabular}

Plant population density (plants/fed) $\{P\}$

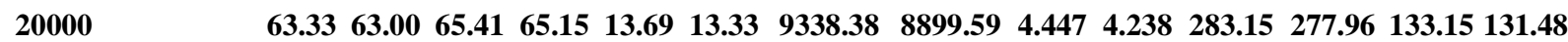

$\begin{array}{llllllllllllllll}24000 & 64.67 & 64.11 & 66.93 & 66.37 & 13.33 & 13.22 & 8600.90 & 8554.60 & 4.915 & 4.888 & 297.59 & 300.93 & 146.30 & 147.96\end{array}$

$\begin{array}{lllllllllllllll}28000 & 66.33 & 65.93 & 69.04 & 68.81 & 12.99 & 12.74 & 8033.11 & 7983.61 & 5.355 & 5.322 & 315.93 & 322.59 & 160.00 & 162.59\end{array}$

\begin{tabular}{lllllllllllllll}
\hline L.S.D at 5\% & 0.50 & 0.30 & 0.67 & 0.38 & 0.15 & 0.12 & 90.87 & 176.95 & 0.054 & 0.099 & 4.80 & 5.05 & 2.72 & 3.59 \\
\hline
\end{tabular}

Nitrogen fertilizer rate $(\mathrm{kg} \mathrm{N} / \mathrm{fed})\{\mathrm{N}\}$

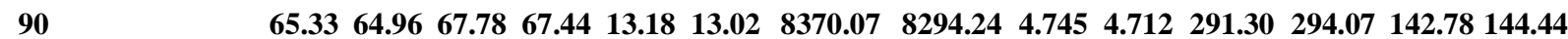

$\begin{array}{lllllllllllllll}120 & 64.78 & 64.30 & 67.11 & 66.74 & 13.36 & 13.10 & 8698.14 & 8496.87 & 4.928 & 4.826 & 300.19 & 301.11 & 146.67 & 147.04\end{array}$

$\begin{array}{llllllllllllllll}150 & 64.22 & 63.78 & 66.48 & 66.15 & 13.47 & 13.17 & 8904.18 & 8646.69 & 5.044 & 4.911 & 305.19 & 306.30 & 150.00 & 150.56\end{array}$

\begin{tabular}{|c|c|c|c|c|c|c|c|c|c|c|c|c|c|c|}
\hline L.S.D at 5\% & 0.26 & 0.33 & 0.31 & 0.42 & 0.06 & 0.04 & 48.10 & 42.18 & 0.025 & 0.023 & 2.35 & 1.89 & 1.84 & 2.42 \\
\hline \multicolumn{15}{|l|}{ Maize hybrid $\{\mathbf{H}\}$} \\
\hline S.C. 7071 & 64.70 & 65.15 & 66.85 & 67.67 & 13.75 & 13.64 & 8423.12 & 8402.81 & 4.778 & 4.767 & 311.30 & 317.22 & 177.41 & 179.63 \\
\hline S.C. $30 \mathrm{K8}$ & 64.04 & 62.93 & 66.37 & 65.19 & 12.66 & 12.24 & 7980.57 & 7732.50 & 4.526 & 4.400 & 281.67 & 279.44 & 128.89 & 128.33 \\
\hline S.C. 2031 & 65.59 & 64.96 & 68.15 & 67.48 & 13.60 & 13.41 & 9568.69 & 9302.48 & 5.413 & 5.282 & 303.70 & 304.81 & 133.15 & 134.07 \\
\hline L.S.D at 5\% & $\mathbf{0 . 2 9}$ & $\mathbf{0 . 3 3}$ & $\mathbf{0 . 3 7}$ & 0.31 & $\mathbf{0 . 0 7}$ & 0.04 & 74.51 & 47.52 & 0.041 & $\mathbf{0 . 0 2 7}$ & 1.83 & 2.21 & 1.68 & 2.32 \\
\hline $\mathbf{P} \times \mathbf{N}$ & $* *$ & $* *$ & $* *$ & $* *$ & N.S. & N.S. & $* *$ & $* *$ & $* *$ & $* *$ & $* *$ & $* *$ & $* *$ & $* *$ \\
\hline F test $P \times H$ & N.S. & N.S. & N.S. & N.S. & $* *$ & $* *$ & $* *$ & $* *$ & $* *$ & $* *$ & $* *$ & $* *$ & $* *$ & $* *$ \\
\hline Prob. $\mathbf{N} \times \mathbf{H}$ & N.S. & N.S. & N.S. & N.S. & N.S. & N.S. & $* *$ & $* *$ & $* *$ & $* *$ & $* *$ & $* *$ & $* *$ & $* *$ \\
\hline$P \times N \times H$ & N.S. & N.S. & N.S. & N.S. & N.S. & N.S. & $* *$ & $* *$ & $* *$ & $* *$ & $* *$ & $* *$ & $* *$ & $* *$ \\
\hline
\end{tabular}

** Significant and N.S. No significant 
Table 3: Mean values of No. of plants carried two ears/fed, No. of barren plants/fed, No. of ears/fed, No. of kernels/ear, ear weight $(\mathrm{g})$, shelling $\%$ and 100-kernel weight $(\mathrm{g})$ as affected by mean effect of plant population densities, nitrogen fertilizer rates and white single hybrids of maize during 2016 and 2017 seasons.

\begin{tabular}{|c|c|c|c|c|c|c|c|c|c|c|c|c|c|c|c|}
\hline \multirow[t]{2}{*}{ Treatment } & \multirow{2}{*}{$\begin{array}{l}\text { Trait } \\
\text { Season }\end{array}$} & \multicolumn{2}{|c|}{$\begin{array}{l}\text { No. of plants } \\
\text { carried two } \\
\text { ears/fed }\end{array}$} & \multicolumn{2}{|c|}{$\begin{array}{c}\text { No. of barren } \\
\text { plants/fed }\end{array}$} & \multicolumn{2}{|c|}{ No. of ears/fed } & \multicolumn{2}{|c|}{$\begin{array}{c}\text { No. of } \\
\text { kernels/ear }\end{array}$} & \multicolumn{2}{|c|}{$\begin{array}{c}\text { Ear weight } \\
\text { (g) }\end{array}$} & \multicolumn{2}{|c|}{ shelling \% } & \multicolumn{2}{|c|}{$\begin{array}{l}\text { 100-kernel } \\
\text { weight (g) }\end{array}$} \\
\hline & & 2016 & 2017 & 2016 & 2017 & 6 & 2017 & 2016 & 2017 & 2016 & 017 & 2016 & 017 & 2016 & 2017 \\
\hline \multicolumn{16}{|c|}{ Plant population density (plants/fed) $\{\mathbf{P}\}$} \\
\hline 20000 & & 2222.22 & 1600.00 & 7 & 1 & 74 & 203 & 584.70 & 59 & 215.69 & 08 & 82.01 & 81.64 & 34.53 & 33.58 \\
\hline 24000 & & 1348.15 & 1140.74 & 2.22 & 444.44 & 4400.00 & 23600.00 & 510.69 & 532.82 & 181.90 & 185.65 & 80.94 & 80.77 & 32.57 & 31.3 \\
\hline 28000 & & 296.30 & 607.41 & 681.48 & $\mathbf{9 7 7 . 7 8}$ & 26785.19 & 26488.89 & 417.30 & 406.52 & 142.93 & 135.86 & 79.56 & 78.37 & 30.13 & 28.16 \\
\hline L.S.D at 5 & & 287.88 & 306.84 & 0 & 2 & 400.14 & 61 & 5,45 & 1 & 2.93 & 9 & 0.26 & 15 & 0.43 & $\mathbf{0 . 4 3}$ \\
\hline \multicolumn{16}{|c|}{ Nitrogen fertilizer rate (kg N/fed) $\{\mathrm{N}\}$} \\
\hline 90 & & 1051.85 & 977.78 & 518.52 & 711.11 & 23822.22 & 2312 & 472.56 & 469 & 165.97 & 165.11 & 80.39 & 79.86 & 31.25 & 29.80 \\
\hline 120 & & 1274.07 & 1 & 8 & 518.52 & 266.67 & 23466.67 & 504.14 & 516 & 181.31 & 22 & 80.89 & 80.33 & 32.41 & 31.1 \\
\hline 150 & & 1540.74 & 1259.26 & $\mathbf{1 7 7 . 7 8}$ & 311.11 & 24637.04 & 23851.85 & $\mathbf{5 3 5 . 9 9}$ & 546.25 & 193.24 & 192.25 & 81.23 & 80.59 & 33.56 & 32.14 \\
\hline L.S.D at 5 & & 117.88 & & 77 & 95. & 29.02 & 33 & 3.24 & 7.41 & 1.51 & 3.08 & 0.15 & 0.09 & 0.24 & 0.41 \\
\hline \multicolumn{16}{|c|}{ Maize hybrid $\{H\}$} \\
\hline S.C. 7 & & 192.59 & 0 & & 755.56 & 56 & 22 & 495 & 488 & 15 & 163.44 & 84.01 & 82.41 & 29.74 & 28.8 \\
\hline S.C. $30 \mathrm{K8}$ & & 2266.67 & 2029.63 & 207.41 & 355.56 & 25333.33 & 24503.70 & 541.00 & 564.02 & 186.52 & 179.92 & 82.27 & 81.77 & 32.18 & 30.54 \\
\hline S.C. 2031 & & 1407.41 & 859.26 & 400.00 & 429.63 & 24237.04 & 23318.52 & 476.40 & 478.79 & 197.42 & 195.23 & 76.23 & 76.60 & 35.30 & 33.77 \\
\hline \multicolumn{2}{|c|}{ L.S.D at 5\% } & 158.19 & 146.31 & 107.03 & 142.12 & 267.30 & 260.45 & 7.93 & 10.83 & 2.36 & 2.80 & 0.15 & 0.11 & 0.26 & 0.34 \\
\hline \multirow{4}{*}{$\begin{array}{l}F \text { test } \\
\text { Prob. }\end{array}$} & $P \times N$ & $* *$ & $* *$ & $* *$ & $* *$ & $* *$ & $* *$ & $* *$ & $* *$ & $* *$ & $* *$ & $* *$ & $* *$ & $* *$ & $* *$ \\
\hline & $P \times H$ & $* *$ & $* *$ & $* *$ & $* *$ & 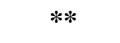 & - & 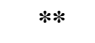 & $*$ & $* *$ & $* *$ & $* *$ & $* *$ & $* *$ & $* *$ \\
\hline & $\mathbf{N} \times \mathrm{H}$ & $* *$ & $* *$ & $* *$ & $* *$ & 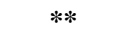 & $* *$ & $*$ & $* *$ & $* *$ & $* *$ & $* *$ & $* *$ & $* *$ & $* *$ \\
\hline & $\mathbf{x} \mathbf{N} \times \mathbf{H}$ & ** & $* *$ & N.S. & N.S. & ** & $* *$ & $* *$ & ** & $* *$ & ** & N.S. & N.S. & N.S. & N.S. \\
\hline
\end{tabular}

** Significant and N.S. No significant

Table 4: Mean values of stover yield/fed $(\mathrm{kg})$, ear yield/fed $(\mathrm{kg})$, grain yield/fed $(\mathrm{kg})$, biological yield/fed $(\mathrm{kg})$, harvest index $(\%)$, nitrogen uptake/fed $(\mathrm{kg})$ and protein yield/fed $(\mathrm{kg})$ as affected by mean effect of plant population densities, nitrogen fertilizer rates and white single hybrids of maize during 2016 and 2017 seasons.

\begin{tabular}{|c|c|c|c|c|c|c|c|c|c|c|c|c|c|c|c|}
\hline \multirow[t]{2}{*}{ Treatment } & \multirow{2}{*}{$\frac{\text { Trait }}{\text { Season }}$} & \multicolumn{2}{|c|}{$\begin{array}{l}\text { Stover yield/fed } \\
(\mathbf{k g})\end{array}$} & \multicolumn{2}{|c|}{ Ear yield/fed (kg) } & \multicolumn{2}{|c|}{$\begin{array}{c}\text { Grain yield/fed } \\
(\mathbf{k g})\end{array}$} & \multicolumn{2}{|c|}{$\begin{array}{c}\text { Biological } \\
\text { yield/fed (kg) }\end{array}$} & \multicolumn{2}{|c|}{$\begin{array}{l}\text { Harvest } \\
\text { index }(\%)\end{array}$} & \multicolumn{2}{|c|}{$\begin{array}{c}\text { Nitrogen } \\
\text { uptake/fed } \\
(\mathrm{kg})\end{array}$} & \multicolumn{2}{|c|}{$\begin{array}{c}\text { Protein } \\
\text { yield/fed (kg) }\end{array}$} \\
\hline & & 2016 & 2017 & 2016 & 2017 & 2016 & 2017 & 2016 & 2017 & 2016 & 2017 & 2016 & 2017 & 2016 & 2017 \\
\hline \multicolumn{16}{|c|}{ Plant population density (plants/fed) $\{P\}$} \\
\hline \multicolumn{2}{|l|}{20000} & 3516.67 & 3511.11 & 3935.19 & 3992.59 & 3214.17 & 325 & 7451.85 & 750 & 43.14 & 43.41 & 56.04 & 56.32 & 350.22 & 352.00 \\
\hline \multicolumn{2}{|l|}{24000} & 4159.26 & 3885.19 & 3850.00 & 3901.85 & 3110.69 & 3146.39 & 8009.26 & 7787.04 & 38.82 & 40.44 & 52.24 & 53.44 & 326.48 & 334.00 \\
\hline \multicolumn{2}{|l|}{28000} & 4796.30 & 4611.11 & 3348.15 & 3190.74 & 2654.26 & 2494.69 & 8144.44 & 7801.85 & 32.52 & 31.85 & 43.03 & 41.04 & 268.96 & 256.48 \\
\hline \multicolumn{2}{|c|}{ L.S.D at $5 \%$} & 183.63 & 125.57 & 25 & 44.64 & 68.58 & 118.03 & 166.98 & 194.31 & 1.15 & 0.99 & 1.38 & 2.06 & 8.63 & 12.89 \\
\hline \multicolumn{16}{|c|}{ Nitrogen fertilizer rate $(\mathrm{kg} \mathrm{N} / \mathrm{fed})\{\mathrm{N}\}$} \\
\hline \multicolumn{2}{|l|}{90} & 3937.04 & 3855.56 & 3353.70 & 3409.26 & 2689.26 & 2722.12 & 7290. & 7264.81 & 37.07 & 37.54 & 44.50 & 45.41 & 278.12 & 283.80 \\
\hline \multicolumn{2}{|l|}{120} & 4196.30 & 4022.22 & 3742.59 & 3755.56 & 3019.10 & 3015.40 & 7938.89 & 7777.78 & 38.21 & 38.84 & 50.91 & 51.19 & 318.17 & 319.94 \\
\hline \multicolumn{2}{|l|}{150} & 4338.89 & 4129.63 & 4037.04 & 3920.37 & 3270.76 & 3158.06 & 8375.93 & 8050.00 & 39.19 & 39.32 & 55.90 & 54.20 & 349.38 & 338.73 \\
\hline \multicolumn{2}{|c|}{ L.S.D at 5\% } & $\mathbf{5 9 . 3 5}$ & 24.43 & 70.15 & 76.24 & 58.54 & 57.94 & 99.93 & 84.26 & 0.39 & 0.38 & 1.05 & 1.13 & 6.57 & 7.05 \\
\hline \multicolumn{16}{|c|}{ Maize hybrid $\{H\}$} \\
\hline \multicolumn{2}{|l|}{ S.C. 7071} & 4492.59 & 4346.30 & 3083.33 & 3229.63 & 2594.72 & 2670.16 & 7575.93 & 7575.93 & 34.38 & 35.16 & 38.14 & 40.84 & 238.35 & 255.24 \\
\hline \multicolumn{2}{|l|}{ S.C. $30 \mathrm{K8}$} & 3629.63 & 3590.74 & 3996.30 & 3859.26 & 3289.30 & 3158.74 & 7625.93 & 7450.00 & 43.20 & 42.49 & 54.83 & 53.71 & 342.66 & 335.67 \\
\hline \multicolumn{2}{|l|}{ S.C. 2031} & 4350.00 & 4070.37 & 4053.70 & 3996.30 & 3095.10 & 3066.68 & 8403.70 & 8066.67 & 36.90 & 38.05 & $\mathbf{5 8 . 3 5}$ & 56.25 & 364.66 & 351.56 \\
\hline \multicolumn{2}{|c|}{ L.S.D at 5\% } & 57.67 & 44.43 & 68.57 & 42.81 & 55.74 & 33.46 & 98.53 & 69.04 & 0.39 & 0.27 & 0.99 & 0.66 & 6.16 & 4.15 \\
\hline \multirow{4}{*}{$\begin{array}{l}\text { F test } \\
\text { Prob. }\end{array}$} & $\mathbf{P} \times \mathbf{N}$ & $* *$ & $* *$ & $* *$ & $* *$ & $* *$ & $* *$ & $* *$ & $* *$ & $* *$ & $* *$ & $* *$ & $* *$ & $* *$ & $* *$ \\
\hline & $\mathbf{P} \times \mathbf{H}$ & $* *$ & $* *$ & $* *$ & $* *$ & $* *$ & $* *$ & $* *$ & $* *$ & $* *$ & $* *$ & $* *$ & $* *$ & $* *$ & $* *$ \\
\hline & $\mathbf{N} \times \mathbf{H}$ & $* *$ & $* *$ & $* *$ & $* *$ & $* *$ & $* *$ & $* *$ & $* *$ & $* *$ & $* *$ & $* *$ & $* *$ & $* *$ & $* *$ \\
\hline & $\mathbf{x} \mathbf{N} \times \mathbf{H}$ & $* *$ & $* *$ & $* *$ & $* *$ & $* *$ & $* *$ & N.S. & N.S. & N.S. & N.S. & N.S. & N.S. & N.S. & N.S. \\
\hline
\end{tabular}

** Significant and N.S. No significant 
The interaction effect between plant population densities and nitrogen fertilizer rates:

Results in Table 2, 3 and 4 showed that the interaction effect among plant population densities and nitrogen fertilizer rates induced significant different on all studied traits except for No. of green leaves/plant during 2016 and 2017 seasons. Results in Tables 5, 6 and 7 indicated that the highest mean values of leaf area index (5.497 and 5.426), plant height $(323.33$ and $327.78 \mathrm{~cm})$, ear height (163.89 and $165.00 \mathrm{~cm})$, No. of barren plants/fed (444.44 and 755.56 plants), No. of ears/fed (27111.11 and 26800.00 ears), stover yield/fed (4972.22 and $4738.89 \mathrm{~kg}$ ) and biological yield/fed (8638.89 and $8200.00 \mathrm{~kg}$ ) in the first and second seasons, respectively were recorded from the highest plant population density (28000 plants/fed) under soil fertilized by the highest rate of nitrogen fertilizer (150 kg N/fed). While, the lowest plant population density (20000 plants/fed) under the same nitrogen fertilizer rate $(150 \mathrm{~kg} \mathrm{~N} / \mathrm{fed})$ gave the maximum mean values for leaf area/plant (9648.37 and 9090.16 $\mathrm{cm}^{2}$ ), No. of plants carried two ears/fed (2622.22 and 1822.22 plants), No. of kernels/ear (621.77 and 633.92 kernels), ear weight (227.63 and $230.62 \mathrm{~g}$ ), shelling percentage ( 82.35 and $81.96 \%)$, 100-kernel weight (35.81 and $34.88 \mathrm{~g}$ ), ear yield/fed (4255.56 and $4200.00 \mathrm{~kg}$ ), grain yield/fed (3490.51 and $3436.54 \mathrm{~kg}$ ), harvest index (43.94 and $43.89 \%)$, nitrogen uptake/fed $(61.74$ and $60.41 \mathrm{~kg})$ and protein yield/fed (385.87 and $377.58 \mathrm{~kg}$ ) as well as recorded significantly the shortest period from planting to 50 $\%$ tasseling (62.89 and 62.56 days) and silking (64.78 and 64.56 days) also gave zero barren plants/fed in the first and second seasons, respectively. The results reported here are in harmony with those obtained by El-Habbak 1996; El-Sheikh 1998; El-Agamy et al. 1999; Saeed et al. 2007; Sallah et al. 2009; Asif et al. 2010; Rafiq et al.2010; Abdulhamid and Adraa 2011; Attia et al. 2011; Bozorgi et al. 2011; Dahmardeh 2011; Zakkam 2011; Dawadi and Sah 2012; Moraditochaee et al. 2012; Adeniyan 2014; Ahmadu 2014 Timlin et al. 2014; Imran et al. 2015; Mahdi and Ismail 2015; Rahman et al. 2016; Sharanabasappa et al. 2017 and Zeleke et al. 2018.

The interaction effect between plant population densities and white single maize hybrids:

Significant effect of the interaction between plant population densities and white single cross hybrids obtained for almost growth, yield components, yield and chemical properties of maize in the both seasons were significant except, No. of days from planting to $50 \%$ tasseling and silking (Tables 2, 3 and 4). Data in Table 5, 6 and 7 showed that planting maize hybrid of S.C. $30 \mathrm{~K} 8$ with 20000 plants/fed recorded the maximum mean values of No. of plants carried two ears/fed (3377.78 and 2622.22 plants), No. of kernels/ear (626.69 and 621.91 kernels) and harvest index (46.31 and $46.16 \%)$ as well as gave the lowest mean values of No. of barren plants/fed (0.00 and 44.44 plants) in the first and second seasons, respectively. While, sowing the same hybrid under the highest plant density (28000 plants/fed) significantly recorded the greatest mean values of No. of ears/fed (27466.67 and 27555.56 ears) during the both seasons, respectively. The maximum grain yield/fed in the first season $(3520.49 \mathrm{~kg})$ was obtained from planting the same hybrid when planting by 24000 plants/fed. Results indicated that the greatest mean values of leaf area/plant (10485.65 and $9793.70 \mathrm{~cm}^{2}$ ), ear weight (237.91 and $233.38 \mathrm{~g}$ ), 100-kernel weight (38.14 and $36.94 \mathrm{~g})$, ear yield/fed $(4472.22$ and $4288.89 \mathrm{~kg})$, nitrogen uptake/fed $(67.88$ and $62.87 \mathrm{~kg}$ ) and protein yield/fed (424.24 and $392.94 \mathrm{~kg}$ ) in the both seasons, respectively, as well as grain yield/fed $(3348.52 \mathrm{~kg})$ in the second season were obtained from planting maize hybrid of S.C. 2031 at the lowest plant density (20000 plants/fed). Meanwhile, planting the same maize hybrid with 28000 plants/fed significantly recorded the maximum mean values of leaf area index (5.831 and 5.825) and biological yield/fed (8666.67 and $8188.89 \mathrm{~kg}$ ) in the first and second seasons, respectively. Data showed that planting maize hybrid of S.C. 7071 at 20000 plants/fed recorded significantly the greatest mean values of No. of green leaves/plant (14.18 and 13.99 leaves) and shelling percentage (85.29 and $84.04 \%)$ during the two seasons, respectively. However, planting maize with the highest plant density (28000 plants/fed) from the same hybrid significantly gave the maximum mean values of plant height (334.44 and $340.56 \mathrm{~cm})$, ear height $(193.33$ and $194.44 \mathrm{~cm})$ and stover yield/fed (5205.56 and $4977.78 \mathrm{~kg}$ ) in the first and second seasons, respectively. These results agree with those reported by El-Habbak 1996; ElSheikh 1998; El-Agamy et al. 1999; El-Koomy 2000; Agasibagil 2006; Saeed et al. 2007; Hassan et al. 2008; Sallah et al. 2009; Sharifi et al. 2009; Gozubenli 2010; Lashkari et al. 2011; Sharifi and Pirzad 2011; Zamir et al. 2011; Dawadi and Sah 2012; Robles et al. 2012; Shafi et al. 2012; Adeniyan 2014; Ahmadu 2014; Karki et al. 2015 and Eyasu et al. 2018 which showed that there was significantly difference among the interaction between plant densities and hybrids in growth, yield components, yield and chemical properties of maize.

The interaction effect between nitrogen fertilizer rates and white single maize hybrids:

Results in Tables 2, 3 and 4 showed that significant effect of the interaction between nitrogen fertilizer rates and white single cross hybrids obtained for almost growth, yield, yield components and kernels chemical properties of maize in the both seasons. While, No. of days from planting to $50 \%$ tasseling and silking as well as No. of green 
leaves/plant were not significantly affected by the interaction between nitrogen fertilizer rates and white single cross hybrids of maize in both seasons. Planting maize hybrid of S.C. $30 \mathrm{~K} 8$ which fertilized by the higher nitrogen rate $(150 \mathrm{~kg} \mathrm{~N} / \mathrm{fed})$ recorded significantly the highest mean values of No. of plants carried two ears/fed (2711.11 and 2177.78 plants), No. of ears/fed (25822.22 and 24844.44 ears), No. of kernels/ear (583.32 and 607.94 kernels), grain yield/fed (3601.27 and $3369.55 \mathrm{~kg}$ ) and harvest index $(44.35$ and $43.26 \%)$ as well as gave the lowest mean values of No. of barren plants/fed (133.33 and 222.22 plants) in the first and second seasons, respectively. Sowing maize hybrid of S.C. 2031 under soil fertilized by $150 \mathrm{~kg} \mathrm{~N} / \mathrm{fed}$ recorded the greatest mean values of leaf area/plant (9842.72 and $\left.9489.33 \mathrm{~cm}^{2}\right)$, leaf area index (5.566 and 5.389), ear weight (210.60 and $206.68 \mathrm{~g}), 100$-kernel weight (36.63 and 35.02 $\mathrm{g})$, ear yield/fed (4405.56 and $4222.22 \mathrm{~kg})$, biological yield/fed (8944.44 and $8411.11 \mathrm{~kg})$, nitrogen uptake/fed $(64.52$ and $60.53 \mathrm{~kg})$ and protein yield/fed $(403.24$ and $378.29 \mathrm{~kg}$ ) during the first and second seasons, respectively. The highest mean values of plant height $(317.78$ and $323.33 \mathrm{~cm})$, ear height (181.11 and $183.33 \mathrm{~cm})$, shelling percentage $(84.37$ and $82.67 \%$ ) and stover yield/fed (4694.44 and $4483.33 \mathrm{~kg}$ ) in the first and second seasons, respectively which were obtained from planting maize hybrid of S.C. 7071 when received $150 \mathrm{~kg}$ $\mathrm{N} /$ fed. These results are in agreement with those obtained by El-Habbak 1996; El-Sheikh 1998; ElAgamy et al. 1999; Saeed et al. 2007; Sallah et al. 2009; Szulc 2009; Bamuaafa et al. 2010; Hokmalipour and Darbandi 2011; Dawadi and Sah 2012; Karasu 2012; Li et al. 2012; Kandil 2013; Radma and Dagash 2013; Adeniyan 2014; Ahmadu 2014; Delibaltova 2014; Khan et al. 2014; Rehman et al. 2014; Hafez and Abdelaal 2015; Majid et al. 2017; Marković et al. 2017 and Ahmad et al. 2018 they found that growth, yield components, yield and chemical properties of maize were significantly affected by the interaction between nitrogen fertilizer rates and maize hybrids.

The interaction effect between plant population densities, nitrogen fertilizer rates and white single maize hybrids:

The effect of the interaction between the three factors under study on leaf area/plant, leaf area index, plant height, ear height, No. of plants carried two ears/fed, No. of ears/fed, No. of kernels/ear, ear weight, stover yield/fed, ear yield/fed and grain yield/fed which significant in the first and second seasons. While, No. of days from planting to $50 \%$ tasseling and silking, No. of green leaves/plant, No. of barren plants/fed, shelling \%, 100-kernel weight, biological yield/fed, harvest index, nitrogen uptake/fed and protein yield/fed were not significantly affected by these interactions ( $F$ test probability are shown in Tables 2, 3 and 4). Data in Tables 8 and 9 showed that planting maize hybrid of S.C. $30 \mathrm{~K} 8$ with 20000 plants/fed when received 150 $\mathrm{kg} \mathrm{N} /$ fed recorded the maximum mean values of No. of plants carried two ears/fed (4000.00 and 2800.00 plants) and No. of kernels/ear (678.75 and 667.44 kernels) in the first and second seasons, respectively. While, sowing the same hybrid in the highest plant density (28000 plants/fed) with soil fertilized by 150 $\mathrm{kg} \mathrm{N} /$ fed significantly recorded the greatest mean values of No. of ears/fed (27733.33 and 27866.67 ears) during the both seasons, respectively. The maximum grain yield/fed in the first season (3824.20 $\mathrm{kg}$ ) was obtained from planting the same hybrid when planting by 24000 plants/fed with soil fertilized by $150 \mathrm{~kg} \mathrm{~N} / \mathrm{fed}$. Results indicated that the greatest mean values of leaf area/plant (10830.10 and 9961.11 $\mathrm{cm}^{2}$ ), ear weight (248.97 and $\left.243.30 \mathrm{~g}\right)$ and ear yield/fed (4783.33 and $4516.67 \mathrm{~kg}$ ) in the both seasons, respectively, as well as grain yield/fed $(3543.97 \mathrm{~kg})$ in the second season were obtained from planting maize hybrid of S.C. 2031 at the lowest plant density (20000 plants/fed) under soil fertilized by $150 \mathrm{~kg} \mathrm{~N} / \mathrm{fed}$. Meanwhile, planting the same maize hybrid with 28000 plants/fed with nitrogen fertilizer rate of $150 \mathrm{~kg} \mathrm{~N} /$ fed significantly recorded the maximum mean values of leaf area index (5.999 and 5.940) in the first and second seasons, respectively. Data showed that planting maize hybrid of S.C. 7071 at 28000 plants/fed and soil fertilized by $150 \mathrm{~kg} \mathrm{~N} /$ fed recorded significantly the greatest mean values of plant height $(343.33$ and $348.33 \mathrm{~cm})$, ear height $(198.33$ and $198.33 \mathrm{~cm})$ and stover yield/fed $(5400.00$ and $5083.33 \mathrm{~kg})$ in the first and second seasons, respectively. These results agree with those reported by El-Habbak 1996; El-Sheikh 1998; ElAgamy et al. 1999; Saeed et al. 2007; Sallah et al. 2009; Dawadi and Sah 2012; Adeniyan 2014 and Ahmadu 2014 which showed that there was significantly difference among the interaction between plant population densities, nitrogen fertilizer rates and hybrids in growth, yield components, yield and chemical properties of maize

\section{Conclusion}

It could be summarized that, the best plant population density when planting maize hybrid of 30K8 was 24000 plants/fed, meanwhile, the best plant density at planting maize hybrids of S.C. 2031 or S.C. 7071 was 20000 plants/fed with soil fertilized by $150 \mathrm{~kg} \mathrm{~N} /$ fed to maximized grain yield/fed. 
Table 5: Mean values of No. of days to $50 \%$ tasseling, No. of days to $50 \%$ silking, No. of green leaves/plant, plant leaf area $\left(\mathrm{cm}^{2}\right)$, leaf area index, plant height $(\mathrm{cm})$ and ear height $(\mathrm{cm})$ as affected by the first order interaction between plant population densities, nitrogen fertilizer rates and white single hybrids of maize during 2016 and 2017 seasons.

\begin{tabular}{|c|c|c|c|c|c|c|c|c|c|c|c|}
\hline \multirow[t]{2}{*}{ Treatment } & \multirow{2}{*}{$\begin{array}{c}\text { Trait } \\
\text { Season }\end{array}$} & \multirow{2}{*}{$\begin{array}{c}\begin{array}{c}\text { No. of days } \\
\text { to } 50 \% \\
\text { tasseling }\end{array} \\
20162017\end{array}$} & $\begin{array}{c}\text { No. of days } \\
\text { to } 50 \% \\
\text { silking } \\
\end{array}$ & $\begin{array}{l}\text { No. of green } \\
\text { leaves/plant }\end{array}$ & \multicolumn{2}{|c|}{$\begin{array}{l}\text { Plant leaf area } \\
\qquad\left(\mathrm{cm}^{2}\right)\end{array}$} & \multirow{2}{*}{$\begin{array}{c}\begin{array}{c}\text { Leaf area } \\
\text { index }\end{array} \\
20162017\end{array}$} & \multicolumn{2}{|c|}{$\begin{array}{c}\text { Plant height } \\
\text { (cm) }\end{array}$} & \multicolumn{2}{|c|}{$\begin{array}{c}\text { Ear height } \\
(\%)\end{array}$} \\
\hline & & & 20162017 & $2016 \quad 2017$ & 2016 & 2017 & & 2016 & 2017 & 2016 & 2017 \\
\hline
\end{tabular}

Interaction between nitrogen fertilizer rates and plant population densities

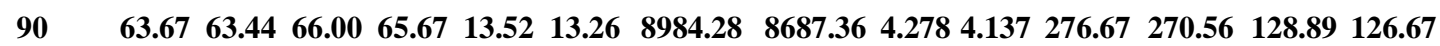

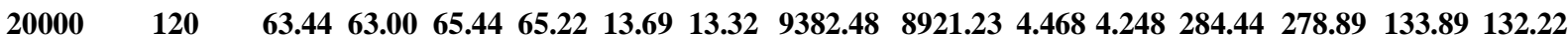

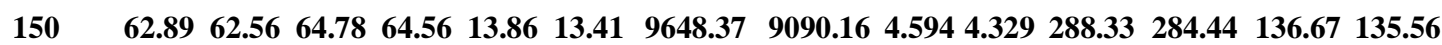

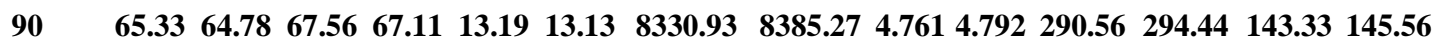

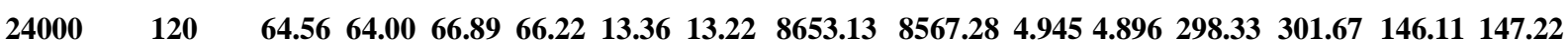

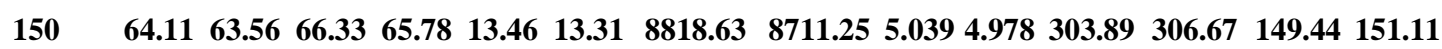

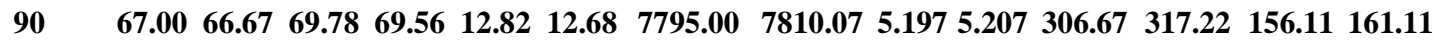

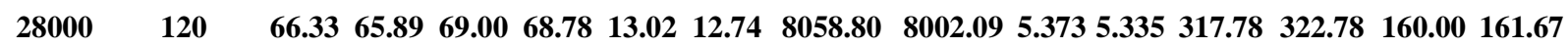

$\begin{array}{lllllllllllllll}150 & 65.67 & 65.22 & 68.33 & 68.11 & 13.11 & 12.80 & 8245.53 & 8138.67 & 5.497 & 5.426 & 323.33 & 327.78 & 163.89 & 165.00\end{array}$

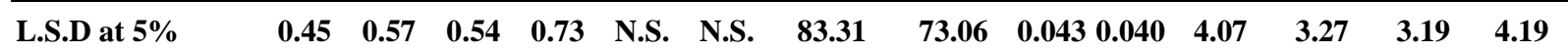

Interaction between plant population densities and maize hybrids

S.C. $7071 \quad 63.11 \quad 63.67 \quad 64.8965 .89 \quad 14.18 \quad 13.99 \quad 9009.00 \quad 8927.06 \quad 4.2904 .251 \quad 291.11296 .67 \quad 162.78 \quad 165.00$

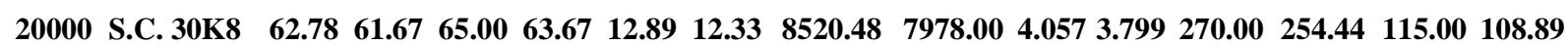

S.C. $2031 \quad 64.11 \quad 63.67 \quad 66.33 \quad 65.89 \quad 14.00 \quad 13.67 \quad 10485.65 \quad 9793.704 .9934 .664 \quad 288.33 \quad 282.78 \quad 121.67 \quad 120.56$

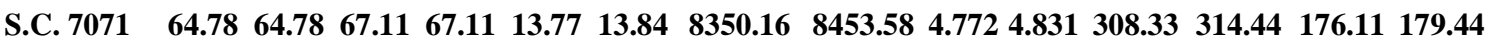

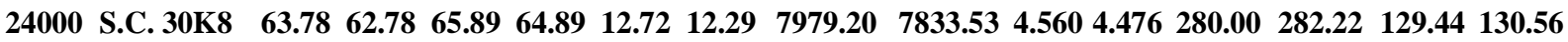

S.C. $2031 \quad 65.44 \quad 64.78$ 67.78 $67.11 \quad 13.51 \quad 13.53 \quad 9473.34 \quad 9376.695 .4135 .358 \quad 304.44 \quad 306.11 \quad 133.33 \quad 133.89$

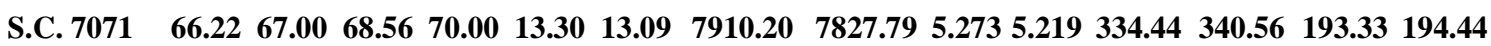

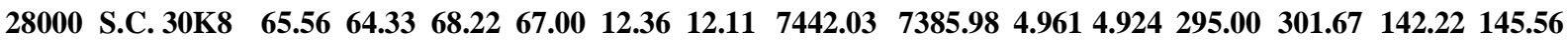

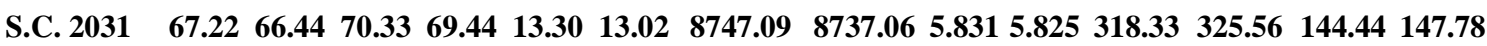

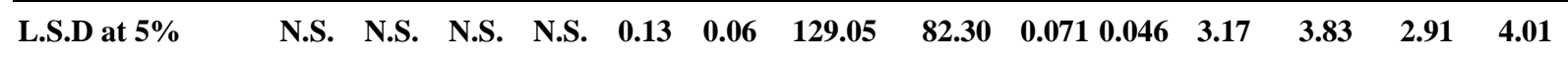

Interaction between nitrogen fertilizer rates and maize hybrids

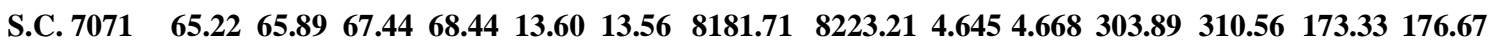

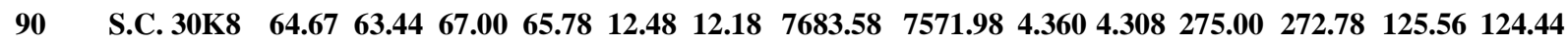

S.C. $2031 \quad 66.1165 .56 \quad 68.8968 .11 \quad 13.46 \quad 13.33 \quad 9244.92 \quad 9087.52 \quad 5.2305 .160 \quad 295.00 \quad 298.89 \quad 129.44 \quad 132.22$

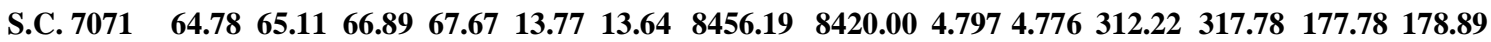

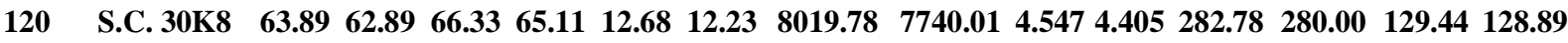

S.C. $2031 \quad 65.67 \quad 64.8968 .11 \quad 67.44 \quad 13.62 \quad 13.41 \quad 9618.44 \quad 9330.605 .4425 .298 \quad 305.56 \quad 305.56 \quad 132.78 \quad 133.33$

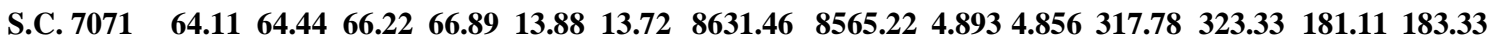

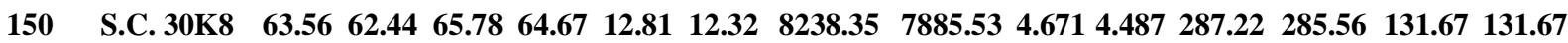

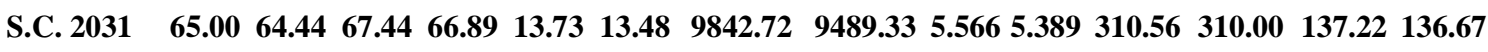

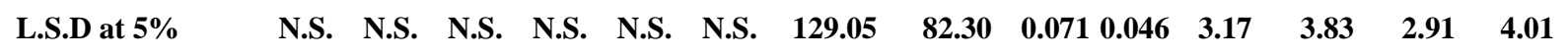


Table 6: Mean values of No. of plants carried two ears/fed, No. of barren plants/fed, No. of ears/fed, No. of kernels/ear, ear weight ( $\mathrm{g}$ ), shelling \% and 100-kernel weight $(\mathrm{g})$ as affected by the first order interaction between plant population densities, nitrogen fertilizer rates and white single hybrids of maize during 2016 and 2017 seasons.

\begin{tabular}{|c|c|c|c|c|c|c|c|c|c|c|c|c|c|c|c|}
\hline \multirow[t]{2}{*}{ Treatment } & \multirow{2}{*}{$\begin{array}{l}\text { Trait } \\
\text { Season }\end{array}$} & \multicolumn{2}{|c|}{$\begin{array}{c}\text { No. of plants } \\
\text { carried two } \\
\text { ears/fed }\end{array}$} & \multicolumn{2}{|c|}{$\begin{array}{l}\text { No. of barren } \\
\text { plants/fed }\end{array}$} & \multicolumn{2}{|c|}{ No. of ears/fed } & \multicolumn{2}{|c|}{$\begin{array}{c}\text { No. of } \\
\text { kernels/ear }\end{array}$} & \multicolumn{2}{|c|}{ Ear weight $(g)$} & \multicolumn{2}{|c|}{ shelling \% } & \multicolumn{2}{|c|}{$\begin{array}{l}\text { 100-kernel } \\
\text { weight (g) }\end{array}$} \\
\hline & & 2016 & 2017 & 2016 & 2017 & 2016 & 2017 & 2016 & 2017 & 2016 & 2017 & 2016 & 2017 & 2016 & 2017 \\
\hline \multicolumn{16}{|c|}{ Interaction between nitrogen fertilizer rates and plant population densities } \\
\hline \multirow{3}{*}{20000} & 90 & 1866.67 & 1377.78 & 177.78 & 222.22 & 21066.67 & 20000.00 & $\mathbf{5 4 7 . 3 2}$ & 540.40 & 201.53 & 201.72 & 81.61 & 81.28 & 33.24 & 32.10 \\
\hline & 120 & 2177.78 & 1600.00 & 44.44 & 133.33 & 21555.56 & 20311.11 & 585.02 & 602.60 & 217.90 & 218.90 & 82.06 & 81.69 & 34.52 & 33.77 \\
\hline & 150 & 2622.22 & 1822.22 & 0.00 & 0.00 & 22000.00 & 20755.56 & 621.77 & 633.92 & 227.63 & 230.62 & 82.35 & 81.96 & 35.81 & 34.88 \\
\hline \multirow{3}{*}{24000} & 90 & 1066.67 & 977.78 & 400.00 & 666.67 & 24044.44 & 23155.56 & 476.62 & 492.28 & 165.00 & 170.88 & 80.46 & 80.38 & 31.26 & 29.94 \\
\hline & 120 & 1377.78 & 1155.56 & 177.78 & 488.89 & 24355.56 & 23644.44 & 510.17 & 534.96 & 183.22 & 188.52 & 80.97 & 80.84 & 32.68 & 31.62 \\
\hline & 150 & 1600.00 & 1288.89 & 88.89 & 177.78 & 24800.00 & 24000.00 & $\mathbf{5 4 5 . 2 7}$ & 571.21 & 197.48 & 197.54 & 81.40 & 81.07 & 33.77 & 32.60 \\
\hline \multirow{3}{*}{28000} & 90 & 222.22 & $\mathbf{5 7 7 . 7 8}$ & 977.78 & 1244.44 & 26355.56 & 26222.22 & 393.75 & 375.33 & 131.37 & 122.74 & 79.12 & 77.93 & 29.24 & 27.36 \\
\hline & 120 & 266.67 & 577.78 & 622.22 & $\mathbf{9 3 3 . 3 3}$ & 26888.89 & 26444.44 & 417.22 & 410.60 & 142.82 & 136.24 & 79.63 & 78.45 & 30.03 & 28.16 \\
\hline & 150 & 400.00 & 666.67 & 444.44 & 755.56 & 27111.11 & 26800.00 & 440.93 & 433.63 & 154.60 & 148.58 & 79.94 & 78.74 & 31.10 & 28.96 \\
\hline \multicolumn{2}{|c|}{ L.S.D at $5 \%$} & 204.17 & 151.41 & 179.73 & 164.60 & 396.67 & 524.52 & 5.62 & 12.83 & 2.62 & 5.33 & 0.26 & 0.16 & 0.42 & 0.71 \\
\hline
\end{tabular}

Interaction between plant population densities and maize hybrids

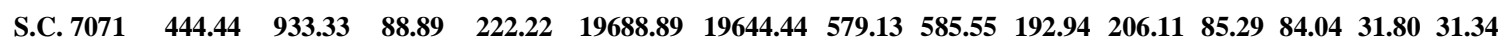

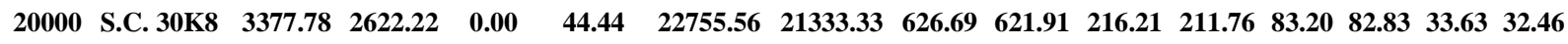

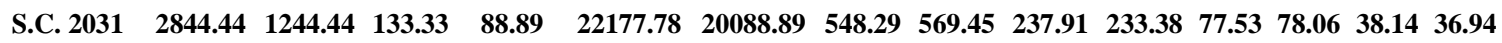

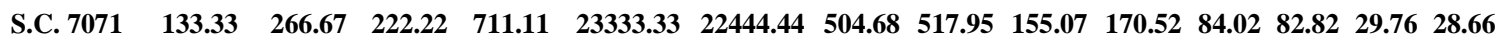

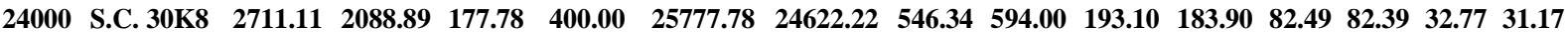

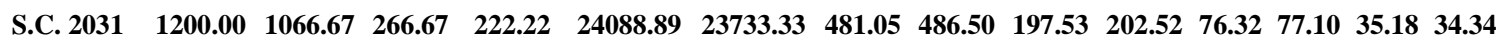

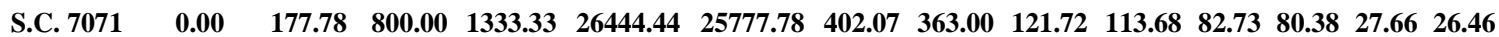
$\begin{array}{llllllllllllllll}28000 & \text { S.C. } 30 \mathrm{~K} 8 & 711.11 & 1377.78 & 444.44 & 622.22 & 27466.67 & 27555.56 & 449.98 & 476.15 & 150.26 & 144.11 & 81.11 & 80.08 & 30.13 & 28.00\end{array}$ $\begin{array}{llllllllllllllll}\text { S.C. } 2031 & 177.78 & 266.67 & \mathbf{8 0 0 . 0 0} & 977.78 & 26444.44 & 26133.33 & 399.85 & 380.40 & 156.81 & 149.78 & 74.85 & 74.65 & 32.59 & 30.01\end{array}$

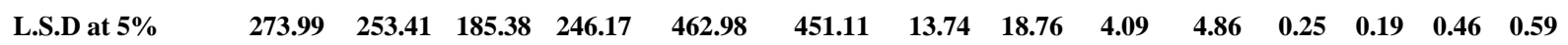

Interaction between nitrogen fertilizer rates and maize hybrids

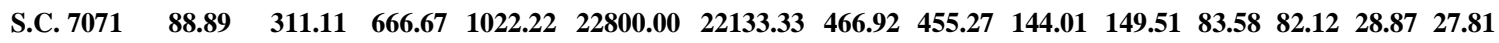

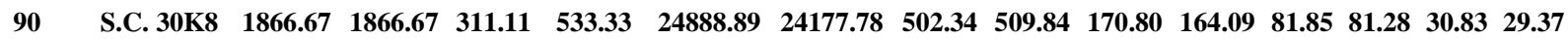

$\begin{array}{lllllllllllllll}\text { S.C. } 2031 & 1200.00 & 755.56 & 577.78 & 577.78 & 23777.78 & 23066.67 & 448.42 & 442.90 & 183.09 & 181.74 & 75.75 & 76.19 & 34.04 & 32.22\end{array}$

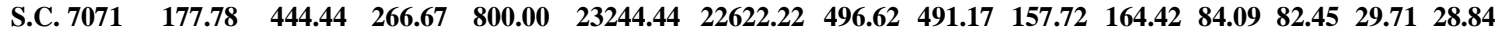

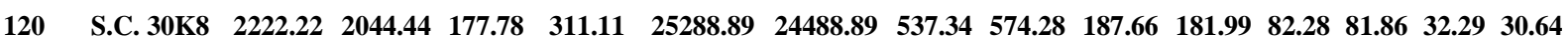

$\begin{array}{lllllllllllllll}\text { S.C. } 2031 & 1422.22 & 844.44 & 400.00 & 444.44 & 24266.67 & 23288.89 & 478.45 & 482.70 & 198.57 & 197.26 & 76.30 & 76.66 & 35.23 & 34.06\end{array}$

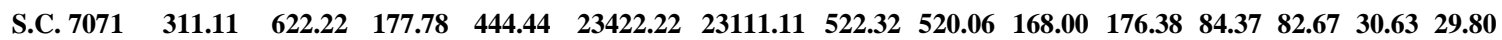

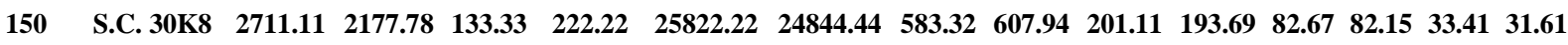

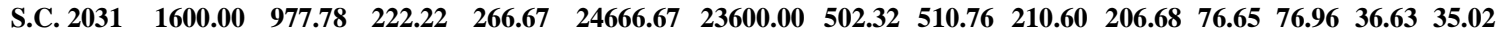

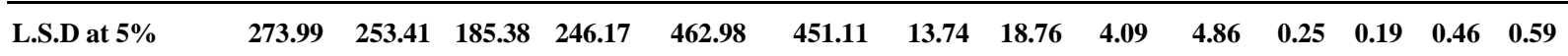


Table 7: Mean values of stover yield/fed $(\mathrm{kg})$, ear yield/fed $(\mathrm{kg})$, grain yield/fed $(\mathrm{kg})$, biological yield/fed $(\mathrm{kg})$, harvest index $(\%)$, nitrogen uptake/fed $(\mathrm{kg})$ and protein yield/fed $(\mathrm{kg})$ as affected by the first order interaction between plant population densities, nitrogen fertilizer rates and white single hybrids of maize during 2016 and 2017 seasons.

\begin{tabular}{|c|c|c|c|c|c|c|c|c|c|c|c|c|c|c|}
\hline \multirow[t]{2}{*}{ Treatment } & \multirow{2}{*}{$\begin{array}{c}\text { Trait } \\
\text { Season }\end{array}$} & \multicolumn{2}{|c|}{$\begin{array}{c}\text { Stover yield/fed } \\
(\mathbf{k g})\end{array}$} & \multicolumn{2}{|c|}{$\underset{(\mathrm{kg})}{\text { Ear yield/fed }}$} & \multicolumn{2}{|c|}{$\underset{\text { (kg) }}{\text { Grain yield/fed }}$} & \multicolumn{2}{|c|}{$\begin{array}{c}\text { Biological } \\
\text { yield/fed (kg) }\end{array}$} & \multicolumn{2}{|c|}{$\begin{array}{c}\text { Harvest } \\
\text { index }(\%)\end{array}$} & \multicolumn{2}{|c|}{$\begin{array}{c}\text { Nitrogen } \\
\text { uptake/fed } \\
(\mathrm{kg})\end{array}$} & $\begin{array}{c}\text { Protein } \\
\text { yield/fed (kg) }\end{array}$ \\
\hline & & & & & & & & & & & & 2016 & 2017 & 2017 \\
\hline
\end{tabular}

Interaction between plant population densities and nitrogen fertilizer rates

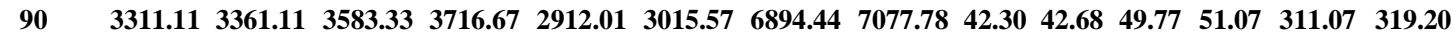

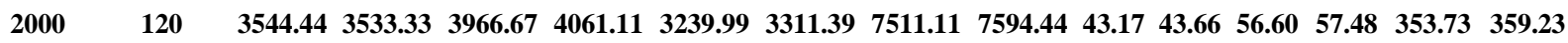

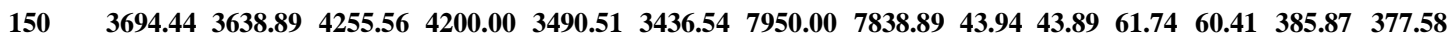

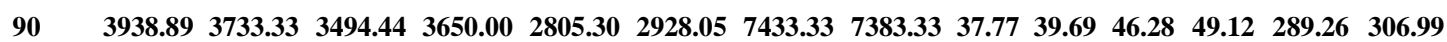

$\begin{array}{llllllllllllllll}24000 & 120 & 4188.89 & 3911.11 & 3866.67 & 3955.56 & 3124.07 & 3192.54 & 8055.56 & 7866.67 & 38.81 & 40.64 & 52.51 & 54.22 & 328.20 & 338.88\end{array}$

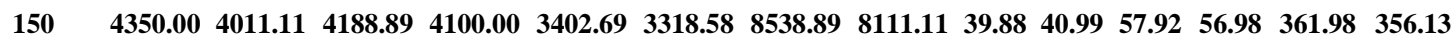

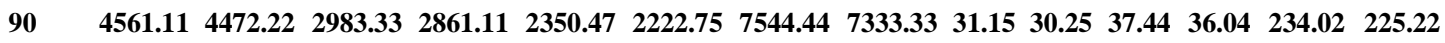

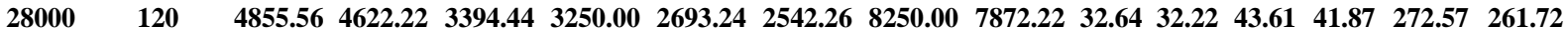

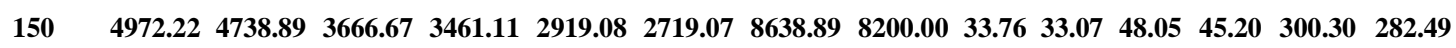

\begin{tabular}{lllllllllllllll}
\hline L.S.D at 5\% & 102.80 & 42.31 & 121.50 & 132.05 & 101.39 & 100.36 & 173.08 & 145.94 & 0.68 & 0.66 & 1.82 & 1.96 & 11.37 & 12.23
\end{tabular}

Interaction between plant population densities and maize hybrids

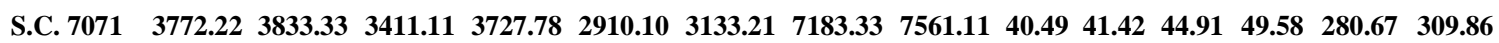

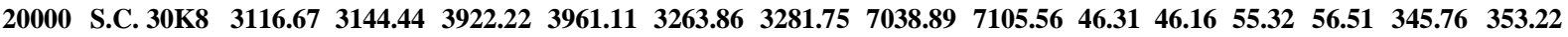

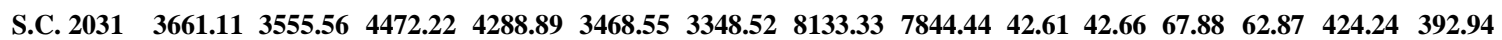

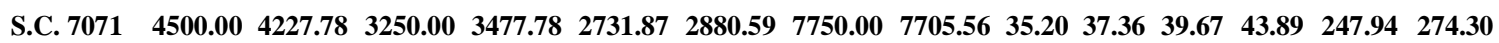

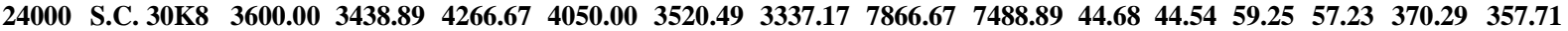

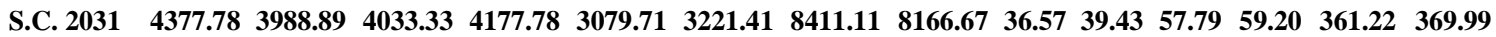

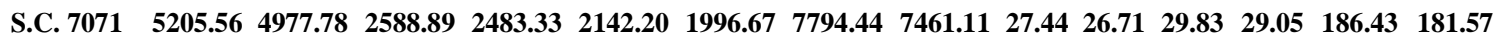

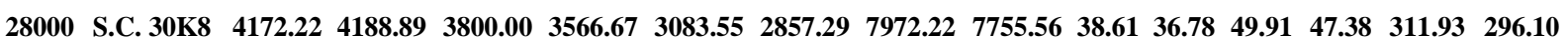
$\begin{array}{llllllllllllllll}\text { S.C. } 2031 & 5011.11 & 4666.67 & 3655.56 & 3522.22 & 2737.05 & 2630.12 & 8666.67 & 8188.89 & 31.51 & 32.07 & 49.36 & 46.68 & 308.52 & 291.76\end{array}$

\begin{tabular}{lllllllllllllll}
\hline L.S.D at 5\% & 99.89 & 76.96 & 118.76 & 74.14 & 96.54 & 57.96 & 170.66 & 119.59 & 0.68 & 0.46 & 1.71 & 1.15 & 10.67 & 7.19
\end{tabular}

Interaction between nitrogen fertilizer rates and maize hybrids

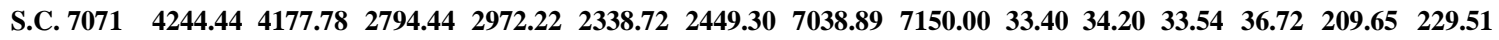

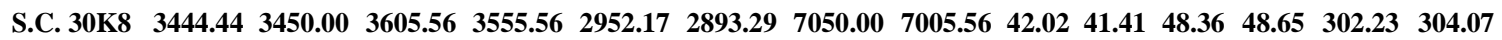

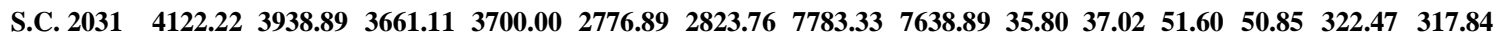

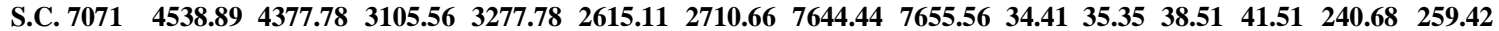

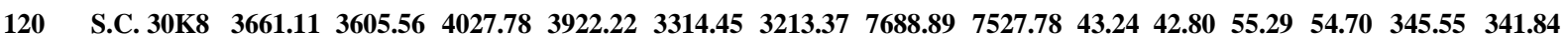

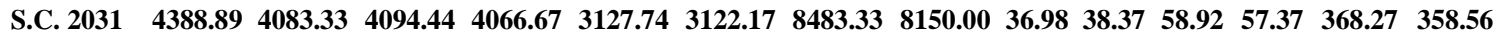

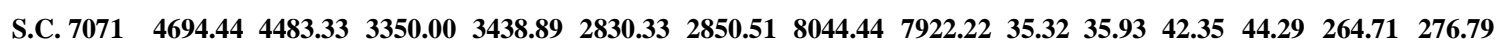

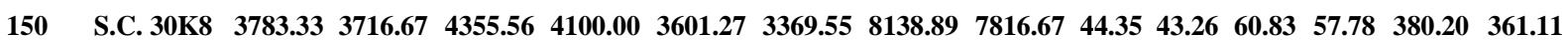

S.C. $2031 \quad 4538.89 \quad 4188.89 \quad 4405.56 \quad 4222.22 \quad 3380.67 \quad 3254.12 \quad 8944.44 \quad 8411.11 \quad 37.91 \quad 38.76 \quad 64.52 \quad 60.53 \quad 403.24 \quad 378.29$

\begin{tabular}{llllllllllllllll}
\hline L.S.D at 5\% & 99.89 & 76.96 & 118.76 & 74.14 & 96.54 & 57.96 & 170.66 & 119.59 & 0.68 & 0.46 & 1.71 & 1.15 & 10.67 & 7.19 \\
\hline
\end{tabular}


Table 8: Mean values of plant leaf area $\left(\mathrm{cm}^{2}\right)$, leaf area index, plant height $(\mathrm{cm})$, ear height $(\mathrm{cm})$, No. of plants carried two ears/fed and No. of barren plants/fed as affected by the second order interaction between plant population densities, nitrogen fertilizer rates and white single hybrids of maize during 2016 and 2017 seasons.

\begin{tabular}{|c|c|c|c|c|c|c|c|c|c|c|c|c|}
\hline \multicolumn{3}{|c|}{ Trait } & \multicolumn{2}{|c|}{$\begin{array}{l}\text { Plant leaf area } \\
\left(\mathrm{cm}^{2}\right)\end{array}$} & \multicolumn{2}{|c|}{$\begin{array}{l}\text { Leaf area } \\
\text { index }\end{array}$} & \multicolumn{2}{|c|}{$\begin{array}{l}\text { Plant height } \\
\text { (cm) }\end{array}$} & \multicolumn{2}{|c|}{ Ear height (\%) } & \multicolumn{2}{|c|}{$\begin{array}{c}\text { No. of plants } \\
\text { carried two } \\
\text { ears/fed } \\
\end{array}$} \\
\hline PD & $\mathbf{N F}$ & MH & 2016 & 2017 & 2016 & 2017 & 2016 & 2017 & 2016 & 2017 & 2016 & 2017 \\
\hline & & S.C. 7071 & 8685.57 & 8651.91 & 4.136 & 4.120 & 285.00 & 288.33 & 158.33 & 160.00 & 266.67 & 666.67 \\
\hline & 90 & S.C. $30 \mathrm{K8}$ & 8157.34 & 7819.32 & 3.884 & 3.723 & 265.00 & 246.67 & 111.67 & 103.33 & 2933.33 & 2400.00 \\
\hline \multirow[t]{11}{*}{20000} & & S.C. 2031 & 10109.92 & 9590.85 & 4.814 & 4.567 & 280.00 & 276.67 & 116.67 & 116.67 & 2400.00 & 1066.67 \\
\hline & & S.C. 7071 & 9048.77 & 8960.62 & 4.309 & 4.267 & 291.67 & 298.33 & 163.33 & 165.00 & 400.00 & 933.33 \\
\hline & & S.C. $30 \mathrm{~K} 8$ & 8581.75 & 7973.95 & 4.087 & 3.797 & 271.67 & 255.00 & 115.00 & 108.33 & 3200.00 & 2666.67 \\
\hline & & S.C. 2031 & 10516.93 & 9829.13 & 5.008 & 4.681 & 290.00 & 283.33 & 123.33 & 123.33 & 2933.33 & 1200.00 \\
\hline & & S.C. 7071 & 9292.66 & 9168.64 & 4.425 & 4.366 & 296.67 & 303.33 & 166.67 & 170.00 & 666.67 & 1200.00 \\
\hline & 150 & S.C. $30 \mathrm{K8}$ & 8822.35 & 8140.73 & 4.201 & 3.877 & 273.33 & 261.67 & 118.33 & 115.00 & 4000.00 & 2800.00 \\
\hline & & S.C. 2031 & 10830.10 & 9961.11 & 5.157 & 4.743 & 295.00 & 288.33 & 125.00 & 121.67 & 3200.00 & 1466.67 \\
\hline & & S.C. 7071 & 8127.00 & 8348.38 & 4.644 & 4.771 & 301.67 & 310.00 & 173.33 & 178.33 & 0.00 & 133.33 \\
\hline & 90 & S.C. $30 \mathrm{K8}$ & 7686.13 & 7676.10 & 4.392 & 4.386 & 273.33 & 275.00 & 126.67 & 126.67 & 2133.33 & 1866.67 \\
\hline & & S.C. 2031 & 9179.66 & 9131.34 & 5.246 & 5.218 & 296.67 & 298.33 & 130.00 & 131.67 & 1066.67 & 933.33 \\
\hline & & S.C. 7071 & 8386.11 & 8459.75 & 4.792 & 4.834 & 310.00 & 315.00 & 176.67 & 178.33 & 133.33 & 266.67 \\
\hline \multirow[t]{9}{*}{24000} & 120 & S.C. $30 \mathrm{K8}$ & 8032.13 & 7839.75 & 4.590 & 4.480 & 280.00 & 283.33 & 130.00 & 131.67 & 2800.00 & 2133.33 \\
\hline & & S.C. 2031 & 9541.16 & 9402.33 & 5.452 & 5.373 & 305.00 & 306.67 & 131.67 & 131.67 & 1200.00 & 1066.67 \\
\hline & & S.C. 7071 & 8537.37 & 8552.61 & 4.878 & 4.887 & 313.33 & 318.33 & 178.33 & 181.67 & 266.67 & 400.00 \\
\hline & 150 & S.C. $30 \mathrm{~K} 8$ & 8219.34 & 7984.76 & 4.697 & 4.563 & 286.67 & 288.33 & 131.67 & 133.33 & 3200.00 & 2266.67 \\
\hline & & S.C. 2031 & 9699.19 & 9596.39 & 5.542 & 5.484 & 311.67 & 313.33 & 138.33 & 138.33 & 1333.33 & 1200.00 \\
\hline & & S.C. 7071 & 7732.57 & 7669.35 & 5.155 & 5.113 & 325.00 & 333.33 & 188.33 & 191.67 & 0.00 & 133.33 \\
\hline & 90 & S.C. $30 \mathrm{~K} 8$ & 7207.27 & 7220.52 & 4.805 & 4.814 & 286.67 & 296.67 & 138.33 & 143.33 & 533.33 & 1333.33 \\
\hline & & S.C. 2031 & 8445.17 & 8540.35 & 5.630 & 5.694 & 308.33 & 321.67 & 141.67 & 148.33 & 133.33 & 266.67 \\
\hline & & S.C. 7071 & 7933.68 & 7839.63 & 5.289 & 5.226 & 335.00 & 340.00 & 193.33 & 193.33 & 0.00 & 133.33 \\
\hline \multirow[t]{5}{*}{28000} & 120 & S.C. $30 \mathrm{~K} 8$ & 7445.47 & 7406.32 & 4.964 & 4.938 & 296.67 & 301.67 & 143.33 & 146.67 & 666.67 & 1333.33 \\
\hline & & S.C. 2031 & 8797.24 & 8760.34 & 5.865 & 5.840 & 321.67 & 326.67 & 143.33 & 145.00 & 133.33 & 266.67 \\
\hline & & S.C. 7071 & 8064.35 & 7974.40 & 5.376 & 5.316 & 343.33 & 348.33 & 198.33 & 198.33 & 0.00 & 266.67 \\
\hline & 150 & S.C. $30 \mathrm{~K} 8$ & 7673.36 & 7531.10 & 5.116 & 5.021 & 301.67 & 306.67 & 145.00 & 146.67 & 933.33 & 1466.67 \\
\hline & & S.C. 2031 & 8998.87 & 8910.51 & 5.999 & 5.940 & 325.00 & 328.33 & 148.33 & 150.00 & 266.67 & 266.67 \\
\hline \multicolumn{3}{|c|}{ L.S.D at $5 \%$} & 223.53 & 142.56 & 0.123 & 0.081 & 5.49 & 6.63 & 5.04 & 6.96 & 474.57 & 438.93 \\
\hline
\end{tabular}


Table 9: Mean values of No. of ears/fed, No. of kernels/ear, ear weight (g), stover yield/fed (kg), ear yield/fed $(\mathrm{kg})$ and grain yield/fed $(\mathrm{kg})$ as affected by the second order interaction between plant population densities, nitrogen fertilizer rates and white single hybrids of maize during 2016 and 2017 seasons.

\begin{tabular}{|c|c|c|c|c|c|c|c|c|c|c|c|c|c|c|}
\hline \multicolumn{3}{|c|}{ Trait } & \multicolumn{2}{|c|}{ No. of ears/fed } & \multicolumn{2}{|c|}{$\begin{array}{c}\text { No. of } \\
\text { kernels/ear }\end{array}$} & \multicolumn{2}{|c|}{ Ear weight (g) } & \multicolumn{2}{|c|}{$\begin{array}{c}\text { Stover yield/fed } \\
\text { (kg) }\end{array}$} & \multicolumn{2}{|c|}{$\begin{array}{c}\text { Ear yield/fed } \\
(\mathbf{k g})\end{array}$} & \multicolumn{2}{|c|}{$\begin{array}{c}\text { Grain yield/fed } \\
\text { (kg) }\end{array}$} \\
\hline PD & NF & MH & 2016 & 2017 & 2016 & 2017 & 2016 & 2017 & 2016 & 2017 & 2016 & 2017 & 2016 & 2017 \\
\hline & & S.C. 7071 & 19333.33 & 19066.67 & 548.49 & $\mathbf{5 3 7 . 5 6}$ & 179.70 & 187.43 & 3550.00 & 3650.00 & 3133.33 & 3500.00 & 2656.73 & 2931.92 \\
\hline & 90 & S.C. $30 \mathrm{K8}$ & 22400.00 & 20933.33 & 577.66 & 555.22 & 200.77 & 195.73 & 2933.33 & 2983.33 & 3550.00 & 3666.67 & 2946.45 & 3022.69 \\
\hline & & S.C. 2031 & 21466.67 & 20000.00 & 515.81 & 528.42 & 224.13 & 222.00 & 3450.00 & 3450.00 & 4066.67 & 3983.33 & 3132.85 & 3092.09 \\
\hline & & S.C. 7071 & 19733.33 & 19600.00 & 581.31 & 592.88 & 195.13 & 208.60 & 3800.00 & 3866.67 & 3433.33 & 3766.67 & 2933.06 & 3167.14 \\
\hline \multirow[t]{9}{*}{20000} & 120 & S.C. $30 K 8$ & 22533.33 & 21333.33 & 623.65 & 643.07 & 217.93 & 213.27 & 3150.00 & 3166.67 & 3900.00 & 4050.00 & 3244.43 & 3357.51 \\
\hline & & S.C. 2031 & 22400.00 & 20000.00 & 550.10 & $\mathbf{5 7 1 . 8 3}$ & 240.63 & 234.83 & 3683.33 & 3566.67 & 4566.67 & 4366.67 & 3542.49 & 3409.51 \\
\hline & & S.C. 7071 & 20000.00 & 20266.67 & 607.58 & 626.20 & 204.00 & 222.30 & 3966.67 & 3983.33 & 3666.67 & 3916.67 & 3140.51 & 3300.58 \\
\hline & 150 & S.C. $30 \mathrm{K8}$ & 23333.33 & 21733.33 & 678.75 & 667.44 & 229.93 & 226.27 & 3266.67 & 3283.33 & 4316.67 & 4166.67 & 3600.69 & 3465.06 \\
\hline & & S.C. 2031 & 22666.67 & 20266.67 & $\mathbf{5 7 8 . 9 7}$ & 608.11 & 248.97 & 243.30 & 3850.00 & 3650.00 & 4783.33 & 4516.67 & 3730.32 & 3543.97 \\
\hline & & S.C. 7071 & 23066.67 & 21866.67 & 472.68 & 489.20 & 140.80 & 157.40 & 4266.67 & 4033.33 & 2950.00 & 3216.67 & 2463.93 & 2655.32 \\
\hline & 90 & S.C. $30 \mathrm{K8}$ & 25200.00 & 24266.67 & 504.68 & 540.98 & 172.90 & 167.23 & 3433.33 & 3350.00 & 3866.67 & 3800.00 & 3172.63 & 3114.53 \\
\hline & & S.C. 2031 & 23866.67 & 23333.33 & 452.50 & 446.67 & 181.30 & 188.00 & 4116.67 & 3816.67 & 3666.67 & 3933.33 & 2779.33 & 3014.28 \\
\hline & & S.C. 7071 & 23333.33 & 22533.33 & 504.48 & 515.89 & 154.87 & 171.43 & 4516.67 & 4266.67 & 3233.33 & 3533.33 & 2717.64 & 2928.02 \\
\hline \multirow[t]{9}{*}{24000} & 120 & S.C. $30 \mathrm{K8}$ & 25733.33 & 24666.67 & 543.03 & 597.04 & 195.73 & 188.40 & 3616.67 & 3450.00 & 4316.67 & 4116.67 & 3564.64 & 3395.56 \\
\hline & & S.C. 2031 & 24000.00 & 23733.33 & 483.01 & 491.97 & 199.07 & 205.73 & 4433.33 & 4016.67 & 4050.00 & 4216.67 & 3089.95 & 3254.05 \\
\hline & & S.C. 7071 & 23600.00 & 22933.33 & $\mathbf{5 3 6 . 8 7}$ & 548.77 & 169.53 & 182.73 & 4716.67 & 4383.33 & 3566.67 & 3683.33 & 3014.04 & 3058.41 \\
\hline & 150 & S.C. $30 \mathrm{K8}$ & 26400.00 & 24933.33 & 591.30 & 643.99 & 210.67 & 196.07 & $\mathbf{3 7 5 0 . 0 0}$ & 3516.67 & 4616.67 & 4233.33 & 3824.20 & 3501.41 \\
\hline & & S.C. 2031 & 24400.00 & 24133.33 & 507.65 & $\mathbf{5 2 0 . 8 7}$ & 212.23 & 213.83 & 4583.33 & 4133.33 & 4383.33 & 4383.33 & 3369.84 & 3395.90 \\
\hline & & S.C. 7071 & 26000.00 & 25466.67 & 379.60 & 339.05 & 111.53 & 103.70 & 4916.67 & 4850.00 & 2300.00 & 2200.00 & 1895.49 & 1760.66 \\
\hline & 90 & S.C. $30 \mathrm{~K} 8$ & 27066.67 & 27333.33 & 424.68 & 433.33 & 138.73 & 129.30 & 3966.67 & 4016.67 & 3400.00 & 3200.00 & 2737.43 & 2542.66 \\
\hline & & S.C. 2031 & 26000.00 & 25866.67 & 376.97 & 353.60 & 143.83 & 135.23 & 4800.00 & 4550.00 & 3250.00 & 3183.33 & 2418.50 & 2364.91 \\
\hline & & S.C. 7071 & 26666.67 & 25733.33 & 404.08 & 364.75 & 123.17 & 113.23 & 5300.00 & 5000.00 & 2650.00 & 2533.33 & 2194.65 & 2036.81 \\
\hline \multirow[t]{5}{*}{28000} & 120 & S.C. $30 \mathrm{K8}$ & 27600.00 & 27466.67 & 445.34 & 482.74 & 149.30 & 144.30 & 4216.67 & 4200.00 & 3866.67 & 3600.00 & 3134.28 & 2887.03 \\
\hline & & S.C. 2031 & 26400.00 & 26133.33 & 402.24 & 384.31 & 156.00 & 151.20 & $\mathbf{5 0 5 0 . 0 0}$ & 4666.67 & 3666.67 & 3616.67 & 2750.79 & 2702.95 \\
\hline & & S.C. 7071 & 26666.67 & 26133.33 & 422.53 & 385.20 & 130.47 & 124.10 & 5400.00 & 5083.33 & 2816.67 & 2716.67 & 2336.45 & 2192.53 \\
\hline & 150 & S.C. $30 \mathrm{~K} 8$ & 27733.33 & 27866.67 & 479.91 & 512.38 & 162.73 & 158.73 & 4333.33 & 4350.00 & 4133.33 & 3900.00 & 3378.93 & 3142.18 \\
\hline & & S.C. 2031 & 26933.33 & 26400.00 & 420.35 & 403.30 & 170.60 & 162.90 & 5183.33 & 4783.33 & 4050.00 & 3766.67 & 3041.85 & 2822.49 \\
\hline \multicolumn{3}{|c|}{ L.S.D at $5 \%$} & 801.9 & 781.35 & 23.79 & 32.49 & 7.08 & 8.40 & 173.01 & 133.29 & 205.71 & 128.43 & 167.22 & 100.38 \\
\hline
\end{tabular}




\section{References}

A.O.A.C. (1990). Official Methods of Analysis Association of Official Analysis Chemists, $13^{\text {th }}$ Ed., Washington, D. C., U. S. A.

Abdulhamid, I and L. Adraa (2011). Effect of plant density and nitrogen rates on plant growth characters and grain yield of maize (Bassel 2 Hyb.). Demashk J. Agric. Sci., 27 (1): 65-81.

Adeniyan, O. N. (2014). Effect of different population densities and fertilizer rates on the performance of different maize varieties in two rain forest agro ecosystems of South West Nigeria. Afr, J. Plant Sci., 8 (8): 410-415.

Agasibagil, A. B. (2006). Response of maize (Zea mays, L.) genotypes to planting densities in drill sown paddy tract of Karnatka. M. Sci. Thesis. Agron., Fac. Agric. Univ. Agric. Sci., Dharwad, India.

Ahmad, S.; A. A. Khan; M. Kamran; I. Ahmad; S. Ali and S. Fahad (2018). Response of maize cultivars to various nitrogen levels. Eur. Exp. Biol., 8 (1-2): 1-4.

Ahmadu, I. A. (2014). Performance of extra-early maize (Zea mays, L.) varieties as influenced by rate of nitrogen and intra-row spacing. M. Sc. Thesis, Fac. Agric., Ahmadu Bello Univ. Zaria, Nigeria.

Asif, M.; A. Asghar; M. Asghar and H. Mumtaz (2010). Effect of fertilizer levels and plant

to different nitrogen applications under climatic conditions of Plovdiv region. Intl. J. Farm. \& Alli. Sci., 3 (4): 408-412.

El-Agamy, A. I.; G. A. Morshed; F. H. Soliman and M. Kh. Osman (1999). Performance of some yellow maize hybrids under different plant population densities and nitrogen fertilizer levels. J. Agric. Sci, Mansoura Univ., 24 (3): 911-923.

El-Gedwy, E. M. M.; M. R. Gomaa and S. A. H. Allam (2011). Maize yield potential as affected by organic \& mineral nitrogen and tillage. LAP Lambert Academic Publishing, ISBN 978-3-84730842-3, paperback, 286 PP.

El-Gedwy, E. M. M.; M. R. Gomaa and S. A. H. Allam (2012). Maize yield as affected by periods of weed control and plant densities. LAP Lambert Academic Publishing, ISBN 978-3-8484-2443-6, paperback, 216 PP.

El-Habbak, K. E. (1996). Response of some maize verities to plant density and nitrogen fertilization. Annals of Agric. Sci., Moshtohor, 34 (3): 951970.

EL-Hosary A. A. A.; S. A. Sedhom; M. El. M. ELBadawy (2011). Genetic and Biotechnological Studies for Important Traits in Maize. LAP Lambert Academic Publishing, ISBN 978-3-84544108-5, paperback, 280 PP.

El-Koomy, M. B. A. (2000). Canopy characteristics and yield of certain yellow maize hybrids as densities on yield and protein contents of autumn planted maize. Pak. J. Agri. Sci., 47 (3): 201-208.

Attia, A.; C. Shapiro; M. Gomaa; R. Aly and A. Omar (2011). Response of different corn populations to fertigated nitrogen and certain micronutrients in sandy soil. Agri. Sci., 2 (2): 94103.

Bamuaafa, M. S.; K. A. Abd El-Rahman; H. M. Abd El-Rahim and I. A. El-Far (2010). Impact of water stress and nitrogen fertilizer on yield, yield components and quality of maize hybrids (Zea mays, L.). Assiut J. Agric. Sci., 41 (4):41-62.

Black, C.A., and D. D. Evans (1965). Methods of Soil Analysis. Amer. Soc. of Agron., Inc. Pub. Madison, Wisconsin, USA.

Bozorgi, H. R.; H. Z. Doustan; S. M. Sadeghi; A. Keshavarz; A. Faraji; F. Tarighi and E. Azarpour (2011). Study effect of plant density and nitrogen fertilizer on yield and yield components of maize cultivar, (SCI-704). World Appl. Sci. J., 13 (1):147-151.

Dahmardeh, M. (2011). Effect of plant density and nitrogen rate on photosynthesis active radiation absorption and maize yield. American J. Plant Physiol., 6 (1): 44-49.

Dawadi, D. R. and S. K. Sah (2012). Growth and yield of hybrid maize ( $\underline{\text { Zea mays, }}$ L.) in relation to planting density and nitrogen levels during winter season in Nepal. Tropical Agric. Res., 23 (3): 218227.

Delibaltova, V. (2014). Response of maize hybrids influenced by plant density. M. Sci. Thesis, Fac. Agric., Ain Shams Univ., Egypt.

El-Mehy, A. A.; A. M. Sheha and El-S. M.M. ELGedwy (2016). Evaluation of maize and soybean under different intercropping systems. Proc., $6^{\text {th }}$ Field Crop Conf., FCRI, ARC, Giza, Egypt, 22-23 Nov., 485-504.

El-Sheikh, F. T. (1998). Effect of plant population densities on nitrogen use efficiency of some maize verities. Annals of Agric. Sci., Moshtohor, 36 (1): 143-162.

Eyasu, E.; D. Shanka; D. Dalga and E. Elias (2018). Yield response of maize (Zea mays, L.) varieties to row spacing under irrigation at Geleko, Ofa Woreda, Wolaita Zone, Southern Ethiopia. J. Exp. Agric. Inter., 20 (1): 1-10.

Gharibi, A. I. S.; G. Y. M. Hammam; M. E. M. Salwau; S. A. H. Allam and E. M. M. ElGedwy (2016). Response of maize yield to nitrogen fertilization and foliar spray by some microelements. J. Plant Production, Mansoura Univ., 7 (5): 455-463.

Gobeze, Y. L.; G. M. Ceronio and L. D. V. Rensburg (2016). Effect of spatial arrangements of row spacing and plant density on water use and water use efficiency of maize under irrigation. J. Nat. Sci. Res., 6 (1): 13-22.

Gomaa, M. R.; S. A. H. Allam and E. M. M. ElGedwy (2011). Determination of the critical 
period of weed control in maize grown under different plant densities. J. Plant Production, Mansoura Univ., 2 (12): 1861-1878.

Gomez, K. A., and A. A. Gomez (1984). Statistical Procedures for Agricultural Research. 2 ${ }^{\text {nd }}$, (ed). John Wiley and Sons, NY, U.S.A.

Gozubenli, H. (2010). Influence of planting patterns and plant density on performance of maize hybrids in the Eastern Mediterranean conditions. Int. J. Agric. Biol., 12 (4): 556-560.

Hafez, E. M. and Kh. A.A. Abdelaal (2015). Impact of nitrogen fertilization levels on morphophysiological characters and yield quality of some maize hybrids (Zea mays, L.). Egypt. J. Agron., 37 (1): 35-48.

Hassan, M. M. M.; M. A. M. El-Ghonemy and R. S. H. Aly (2008). Response of some maize single cross hybrids to plant density under different Egyptian environmental conditions. J. Agric. Sci. Mansoura Univ., 33 (2): 427-443.

Hokmalipour, S. and M. H. Darbandi (2011). Investigation of nitrogen fertilizer levels on dry matter remobilization of some varieties of corn (Zea mays, L.). World Appl. Sci. J., 12 (6): 862870.

Imran, S.; M. Arif; A. Khan; M. A. Khan; W. Shah and M. Abdul Latif (2015). Effect of nitrogen levels and plant population on yield and yield components of maize. Adv. Crop Sci. Tech., $3(2): 1-7$.

Kandil, A. A.; A. N. Attia; S. A. EL-Moursy and M. M. Abd-Elnaby (2016). Yielding and growth parameters of maize (Zea mays, L.) as affected by different foliar and nitrogen soil fertilization. Adv. Agric. Sci., 4 (3): 13-34.

Kandil, E. E. E. (2013). Response of some maize hybrids (Zea mays, L.) to different levels of nitrogenous fertilization. J. Appl. Sci. Res., 9 (3): 1902-1908.

Karasu, A. (2012). Effect of nitrogen levels on grain yield and some attributes of some hybrid maize cultivars. Bulg. J. Agric. Sci., 18 (1): 42-48.

Karki, T. B.; K. C. Govind; J. Shrestha and J. P. Yadav (2015). Tillage and planting density affect the performance of maize hybrids in Chitwan, Nepal. J. Maize Res. Dev., 1 (1):10-20.

Khan, F.; S. Khan; S. Fahad; S. Faisal; S. Hussain; S. Ali and A. Ali (2014). Effect of different levels of nitrogen and phosphorus on the phenology and yield of maize varieties. Amer. J. Plant Sci., 5: 2582-2590.

Kinfe, H.; T. Yiergalem; R. Alem; W. Redae; Y. Desalegn; G. Welegerima; G. Kifle and S. Husien (2016). Evaluating hybrid maize genotypes for grain yield and yield related traits in north western Tigray, Ethiopia. Inter. J. Res. Agric. For., 3 (12): 17-21.

Lashkari, M.; H. Madani and M. R. Ardakani (2011). Effect of plant density on yield and yield components of different corn (Zea mays, L.) hybrids. Am-Euras. J. Agric. \& Environ. Sci., 10 (3): 450-457.

Li, G.; Z. S. Zhang; H. Y. Gao; P. Liu; S. T. Dong; J. W. Zhang and B. Zhao (2012). Effects of nitrogen on photosynthetic characteristics of leaves from two different stay-green corn (Zea mays, L.) varieties at the grain filling stage. Can. J. Plant Sci., 92: 671-680.

Mahdi, A. H. A. and S. K. A. Ismail (2015). Maize productivity as affected by plant density and nitrogen fertilizer. Int. J. Curr. Microbiol. App. Sci., 4 (6): 870-877.

Majid, M. A.; M. S. Islam; A. EL Sabagh; M. K. Hasan; M. O. Saddam; C. Barutcular; D. Ratnasekera; Kh. A. A. Abdelaal and M.S. Islam (2017). Influence of varying nitrogen levels on growth, yield and nitrogen use efficiency of hybrid maize (Zea mays, L.). J. Exp. Biol. Agric. Sci., 5 (2): 134-142.

Malekabadi, S. R.; A. Pazoki; and M. R. Mehrvar (2014). Evaluating the effects planting date on some quantitative and qualitative characteristics of new maize varieties in the region Rey. Bull. Env. Pharmacol. Life Sci., 3 (3): 189-192.

Mandić, V.; Z. Bijelić; V. Krnjaja; Z. Tomić; A. Stanojković-Sebić; A. Stanojković, and V. Caro- Petrović (2016). The effect of crop density on maize grain yield. Biotech. Animal Husb., 32 (1): 83-90.

Marković, M.; M. Josipović; J. Šoštarić; A. Jambrović and A. Brkić (2017). Response of maize (Zea mays, L.) grain yield and yield components to irrigation and nitrogen fertilization. J. Cen. Eur. Agric., 18 (1): 55-72.

Michigan State University (1983). MSTAT-C: Micro-computer Statistical Program, Version 2. Michigan State University, East Lansing.

Mohsin, A. U.; A. U. H. Ahmad; M. Farooq and S. Ullah (2014). Influence of zinc application through seed treatment and foliar spray on growth, productivity and grain quality of hybrids maize. J. Anim. Plant Sci., 24 (5): 1494:1503.

Moraditochaee, M.; M. K. Motamed; E. Azarpour; R. K. Danesh and H. R. Bozorgi (2012). Effects of nitrogen fertilizer and plant density management in corn farming. ARPN J. Agric. Biol. Sci., 7 (2): 133-137.

Radma, I. A. M. and Y. M. I. Dagash (2013) Effect of different nitrogen and weeding levels on yield of five maize cultivars under irrigation. Univ. J. Agric. Res., 1(4): 119-125.

Rafiq, M. A.; A. Ali; M. A. Malik and M. Hussain (2010). Effect of fertilizer levels and plant densities on yield and protein contents of autumn planted maize. Pak. J. Agri. Sci., 47 (3): 201-208.

Rahman, M. M.; S. K. Paul and M. M. Rahman (2016). Effects of spacing and nitrogen levels on yield and yield contributing characters of maize. J. Bangladesh Agril. Univ., 14 (1): 43-48. 
Rehman, K.; S. Ali; M. W. Pervez; M. Rehman; S. Hussain; G. Aishia and M. S. Khalid (2014). Performance of autumn planted maize hybrids under different fertilizer treatments in semi-arid Punjab Pakistan. J. Glob. Innov. Agric. Soc. Sci., 2 (3): 107-111.

Robles, M.; I. A. Ciampitti and T. J. Vyn (2012). Responses of maize hybrids to twin-row spatial arrangement at multiple plant densities. Agron. J., 104 (6):1747-1756.

Saeed, N. A.; A. S. El-Debaby and A. O. Abdulla (2007). Effect of nitrogenous fertilizers and plant density on growth, physiological characters, yield and it components of two varieties (Zea mays, L.) 2-Effect of nitrogenous fertilizers and plant density on yield and its components of two varieties. Annals of Agric. Sci., Moshtohor, 45 (3): 1-14. In Arabic.

Sallah, P. Y. K.; S. Mukakalisa; A. Nyombayire and P. Mutanyagwa (2009). Response of two maize varieties to density and nitrogen fertilizer in the highland zone of Rwanda. J. Appl. Biosci., 20: 1194-1202.

Sapkota, A.; R. K. Shrestha and D. Chalise (2017). Response of maize to the soil application of nitrogen and phosphorous fertilizers. Int. J. Appl. Sci. Biotechnol., 5(4): 537-541.

Shafi, M.; J. Bakht; S. Ali; H. Khan; M. A. Khan and M. Sharif (2012). Effect of planting density on phenology, growth and yield of maize (Zea mays, L.). Pak. J. Bot., 44(2): 691-696.

Sharanabasappa, H. C.; M. A. Basavanneppa and Koppalkar, B. G. (2017). Productivity of quality protein maize (Zea mays, L.) and soil fertility as influenced by plant population and fertilizer levels under irrigated ecosystem. Int. J. Adv. Biol. Res., 7 (3): 504-508.

Sharifi, R. S. and A. Pirzad (2011). Study of physiological growth indices in maize (Zea mays, L.) hybrids under different plant densities application. Int. J. Agric. Res. \& Rev., 1(1): 2632.

Sharifi, R. S.; M. Sedghi and A. Gholipouri (2009). Effect of population density on yield and yield attributes of maize hybrids. Res. J. Biol. Sci., 4(4): 375-379.

Stickler, F.C. (1964). Row Width and Plant Production Studies. Sixth edition, Iowa state Univ. Press, Ames. U.S.A.

Szulc, P. (2009). Effect of nitrogen fertilization and methods of magnesium application on chlorophyll content, accumulation of mineral components, and morphology of two maize hybrid types in the initial growth period. i. Content of chlorophyll and mineral components. Acta. Sci. Pol. Agric., 8 (2): 43-50.

Takele, E.; Z. Mekonnen; D. Tsegaye and A. Abebe (2017). Effect of intercropping of legumes and rates of nitrogen fertilizer on yield and yield components of maize (Zea mays, L.) at Arba Minch. American J. Plant Sci., 8: 2159-2179.

Timlin, D. J.; D. H. Fleisher; A, R. Kemanian and V. R. Reddy (2014). Plant density and leaf area index effects on the distribution of light transmittance to the soil surface in maize. Agron. J., 106 (5): 1828-1837.

Zakkam, M. (2011). Response of maize (Zea mays, L.) to planting densities and nitrogen levels under late rabi conditions. M. Sc. Thesis, Agric. College, Bapatla, Agric. Univ. India.

Zamir, M. S. I.; A. H. Ahmad; H. M. R. Javeed and T. Latif (2011). growth and yield behaviour of two maize hybrids (Zea mays, L.) towards different plant spacing. Cercetări Agronomice în Moldova, XLIV, 2 (146): 33-40.

Zeleke, A.; G. Alemayehu and G. S. Yihenew (2018). Effects of planting density and nitrogen fertilizer rate on yield and yield related traits of maize (Zea mays, L.) in Northwestern, Ethiopia. Adv. Crop Sci. Tech., 6 (2): 1-5. 


\section{استجابة هجن الذرة الثامية البيضاء للكثافات النباتية ومعدلات التسميد النيتروجيني \\ علي عبد المقصود الحصري" جابر يحيى همام' السعيد محمد محمود الجدوي'محمد الحافظ سيدي

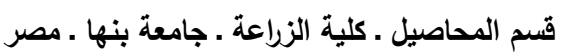

أجريت تجربتان حقليتان في مزرعة مركز البحوث والتجارب الزراعية بكلية الزراعة بمشتهر جامعة بنها (مركز طوخ ـ محافظة القليوبية ـ

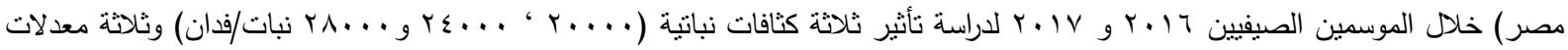

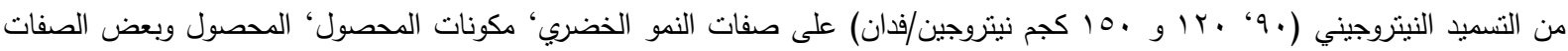

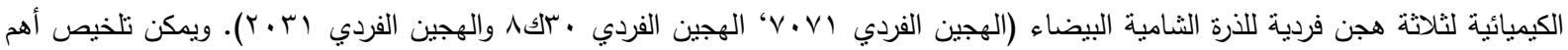
النتائج فيما يلي:.

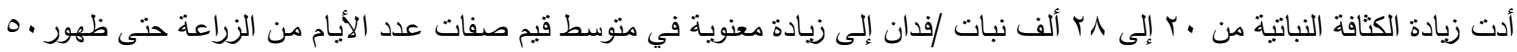

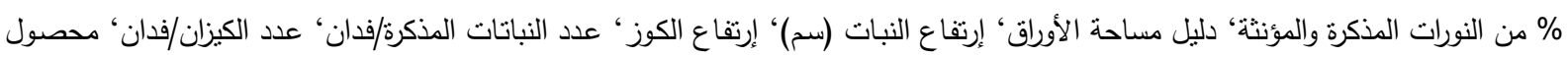
الحطب/فدان (كجم) والمحصول البيولوجي/فدان (كجم) بينما إنخفضت معنوياً متوسط قيم صفات عدد الأوراق الخضراء/نبات، مساحة أوراق النبات

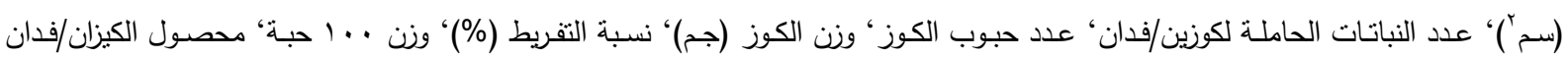

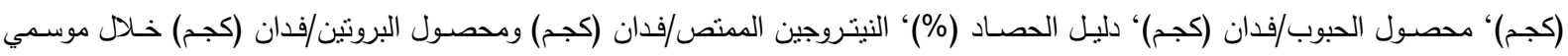
الدراسة.

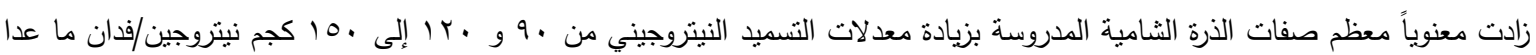
عدد الأيام من الزراعة حتى ظهور •0 \% من النورات المذكرة والمؤنثة وعدد النباتات المذكرة/فدان قلت معنوياً بزيادة التسميد النبتروجيني في كلا الموسمين. إضافة السماد النيتروجيني بمعدل •10 كجم نبتروجين/فدان أعطى معنوياً أفضل القيم في جميع الصفات المنات المدروسة. أوضحت النتائج أن الإختلافات بين الهجن الفردية البيضاء للذرة الثامية تحت الدراسة كانت معنوية في جميع الصفات المدروسة خلال

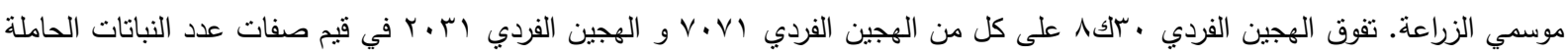
لكوزين/فدان" عدد الكيزان/فدان" عدد حبوب الكوز، محصول الحبوب/فدان ودليل الحصاد وأيضا أعطى أقل قيم في صفة على عدد النباتات

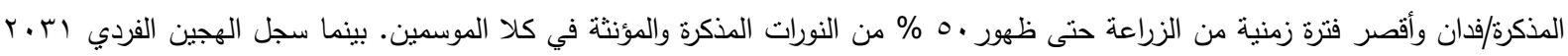

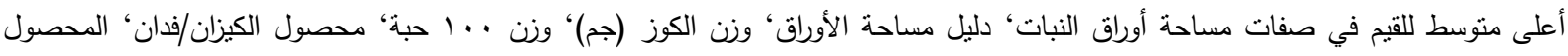

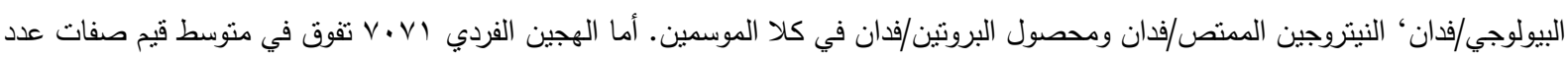
الأوراق الخضراء/نبات، إرتفاع النبات (سم)' إرتفاع الكوز ' نسبة التقريط ومحصول الحطب/فدان خلال موسمي الزراعة.

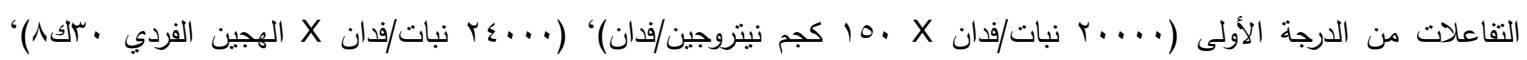

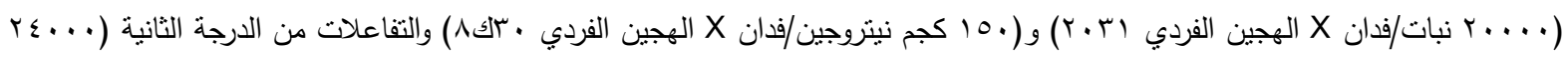

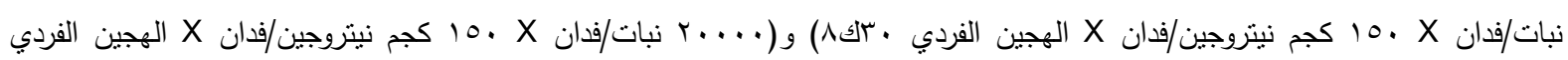

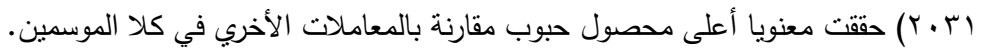

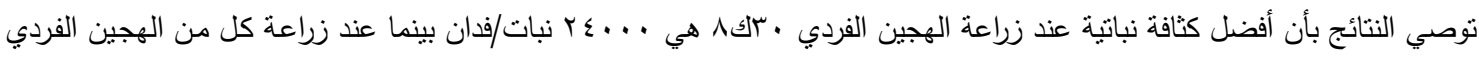

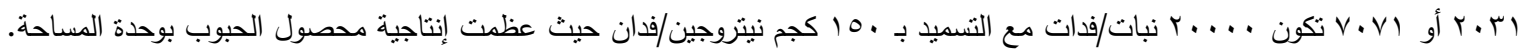

